\title{
GEM-AQ, an on-line global multiscale chemical weather modelling system: model description and evaluation of gas phase chemistry processes
}

\author{
J. W. Kaminski ${ }^{1}$, L. Neary ${ }^{1}$, J. Struzewska ${ }^{2}$, J. C. McConnell ${ }^{1}$, A. Lupu ${ }^{1}$, J. Jarosz ${ }^{1}$, K. Toyota ${ }^{1}$, S. L. Gong ${ }^{3}$, J. Côtée ${ }^{4}$, \\ X. Liu ${ }^{5,}$, K. Chance ${ }^{5}$, and A. Richter ${ }^{6}$ \\ ${ }^{1}$ Atmospheric Modelling and Data Assimilation Laboratory, Centre for Research in Earth and Space Science, York \\ University, Toronto, Canada \\ ${ }^{2}$ Faculty of Environmental Engineering, Warsaw University of Technology, Warsaw, Poland \\ ${ }^{3}$ Science and Technology Branch, Environment Canada, Toronto, Canada \\ ${ }^{4}$ Science and Technology Branch, Environment Canada, Montréal, Canada \\ ${ }^{5}$ Smithsonian Astrophysical Observatory, Cambridge, MA, USA \\ ${ }^{6}$ Institute of Environmental Physics, University of Bremen, Germany \\ * now at: Goddard Earth Sciences and Technology, University of Maryland Baltimore County, Baltimore, MD, USA
}

Received: 23 August 2007 - Published in Atmos. Chem. Phys. Discuss.: 16 October 2007

Revised: 25 February 2008 - Accepted: 30 May 2008 - Published: 27 June 2008

\begin{abstract}
Tropospheric chemistry and air quality processes were implemented on-line in the Global Environmental Multiscale weather prediction model. The integrated model, GEM-AQ, was developed as a platform to investigate chemical weather at scales from global to urban. The current chemical mechanism is comprised of 50 gas-phase species, 116 chemical and 19 photolysis reactions, and is complemented by a sectional aerosol module with 5 aerosols types. All tracers are advected using the semi-Lagrangian scheme native to GEM. The vertical transport includes parameterized subgridscale turbulence and large scale deep convection. Dry deposition is included as a flux boundary condition in the vertical diffusion equation. Wet deposition of gas-phase species is treated in a simplified way, and only below-cloud scavenging is considered. The emissions used include yearly-averaged anthropogenic, and monthly-averaged biogenic, ocean, soil, and biomass burning emission fluxes, as well as $\mathrm{NO}_{\mathrm{x}}$ from lightning. In order to evaluate the ability to simulate seasonal variations and regional distributions of trace gases such as ozone, nitrogen dioxide and carbon monoxide, the model was run for a period of five years (2001-2005) on a global uniform $1.5^{\circ} \times 1.5^{\circ}$ horizontal resolution domain and 28 hy-
\end{abstract}

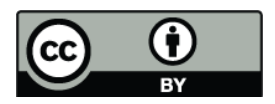

Correspondence to: J. W. Kaminski (jacek@yorku.ca) brid levels extending up to $10 \mathrm{hPa}$. Model results were compared with observations from satellites, aircraft measurement campaigns and balloon sondes. We find that GEM-AQ is able to capture the spatial details of the chemical fields in the middle and lower troposphere. The modelled ozone consistently shows good agreement with observations, except over tropical oceans. The comparison of carbon monoxide and nitrogen dioxide with satellite measurements emphasizes the need for more accurate, year-specific emissions fluxes for biomass burning and anthropogenic sources. Other species also compare well with available observations.

\section{Introduction}

The strategic objective of our project was to develop and evaluate a modelling system for tropospheric chemistry and air quality. In our design we have selected the Global Environmental Multiscale model (GEM) (Côté et al., 1998a) as a host meteorological model for inclusion of air quality processes. The GEM model was developed at the Canadian Meteorological Centre and is used for operational weather prediction in Canada. The GEM model was augmented by implementing air quality chemistry, including the gas phase, aerosol and cloud particles, limited wet chemistry, emission, deposition and transport processes.

Published by Copernicus Publications on behalf of the European Geosciences Union. 

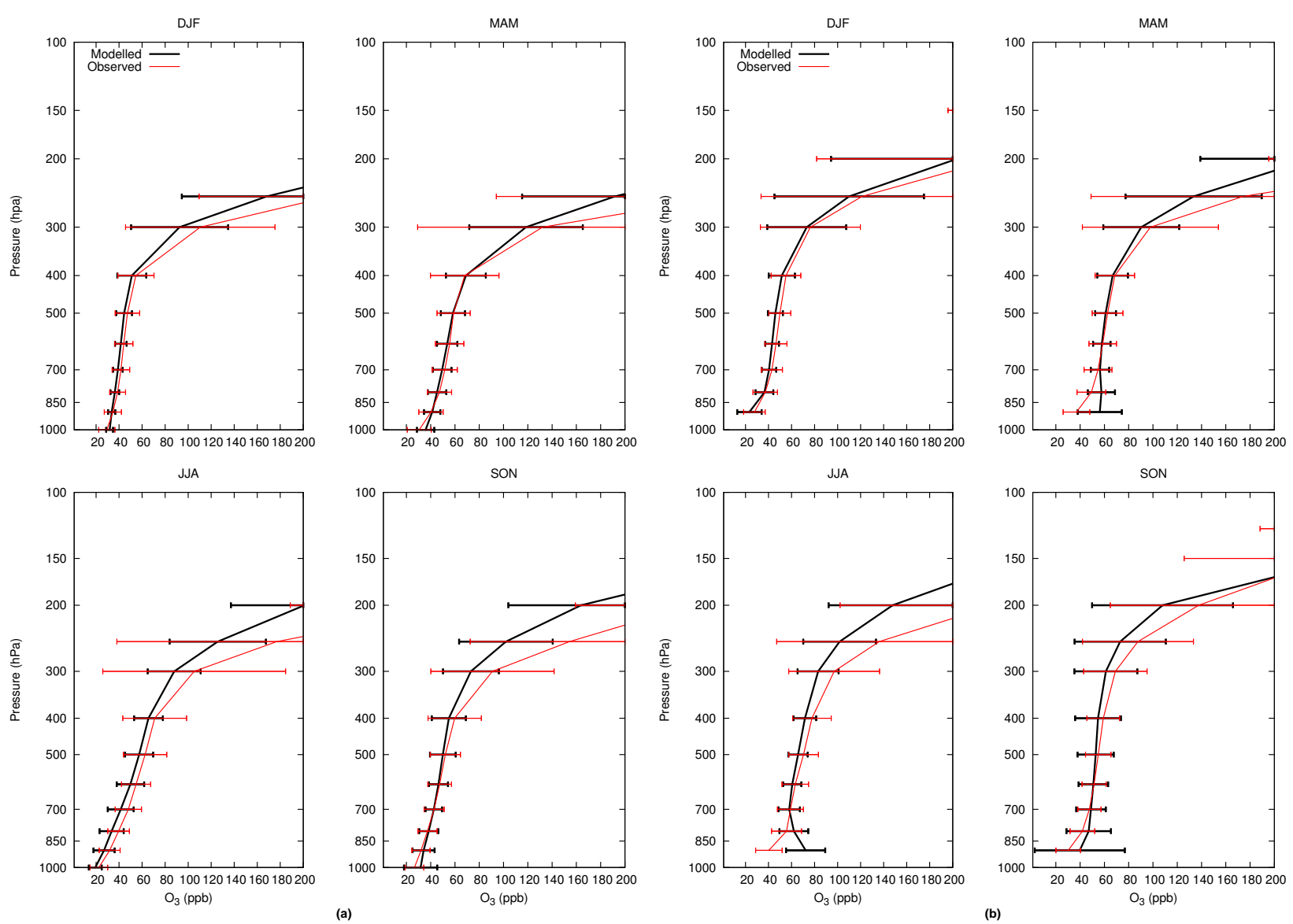

Fig. 1. Seasonal comparison of GEM-AQ and ozonesonde climatology for (a) Churchill and (b) Hohenpeissenberg stations. Horizontal bars correspond to one standard deviation.

The integrated model, which we here call GEM-AQ, serves as a platform for performing scientific studies on processes and applications. The GEM-AQ model has been run in a number of configurations ranging from a global uniform domain (this study), global variable resolution for regional scenarios (O'Neill et al., 2006), to high resolution studies (Struzewska and Kaminski, 2008). GEM-AQ has also been augmented to study persistent organic pollutants (POPs) globally (Gong et al., 2007; Huang et al., 2007). In these studies, GEM-AQ showed good agreement with observations of aerosol optical properties, gaseous species concentrations, and seasonal variation of POPs in the atmosphere.

GEM-AQ was run for 5 years (2001-2005) on a global uniform $1.5^{\circ} \times 1.5^{\circ}$ resolution domain $(240 \times 120$ grid points $)$ and 28 hybrid levels extending to $10 \mathrm{hPa}$. The objectives of this simulation were to derive a multi-year model climatology, to examine seasonal variation and regional distribution, to evaluate global emissions, and to provide chemical initial and boundary conditions for high resolution model simulations.
In order to evaluate the model, we compared simulated ozone with ozonesonde observations from SHADOZ (Southern Hemisphere ADditional OZonesondes) (Thompson et al., 2003a,b) as well as climatological ozonesonde observations (Logan, 1999), GOME (Global Ozone Monitoring Experiment) satellite observations (Burrows et al., 1999) and surface station data (World Data Centre for Greenhouse Gases, http://gaw.kishou.go.jp/wdegg.html). Modelled nitrogen dioxide is compared with SCIAMACHY (Scanning Imaging Absorption Spectrometer for Atmospheric Chartography) satellite observations (Burrows et al., 1995; Bovensmann et al., 1999) and measurements from the TRACE-A (Transport and Atmospheric Chemistry near the EquatorAtlantic) (Fishman et al., 1996) are used to evaluate species such as nitric acid, hydrogen peroxide and others. Modelled CO concentrations are compared with MOPITT (Measurements Of Pollution In The Troposphere) (Drummond, 1992; Drummond and Mand, 1996) satellite data.

Comparison with the satellite data provides a global and seasonal perspective on model performance and characteristics at appropriate resolution. The species that we have 

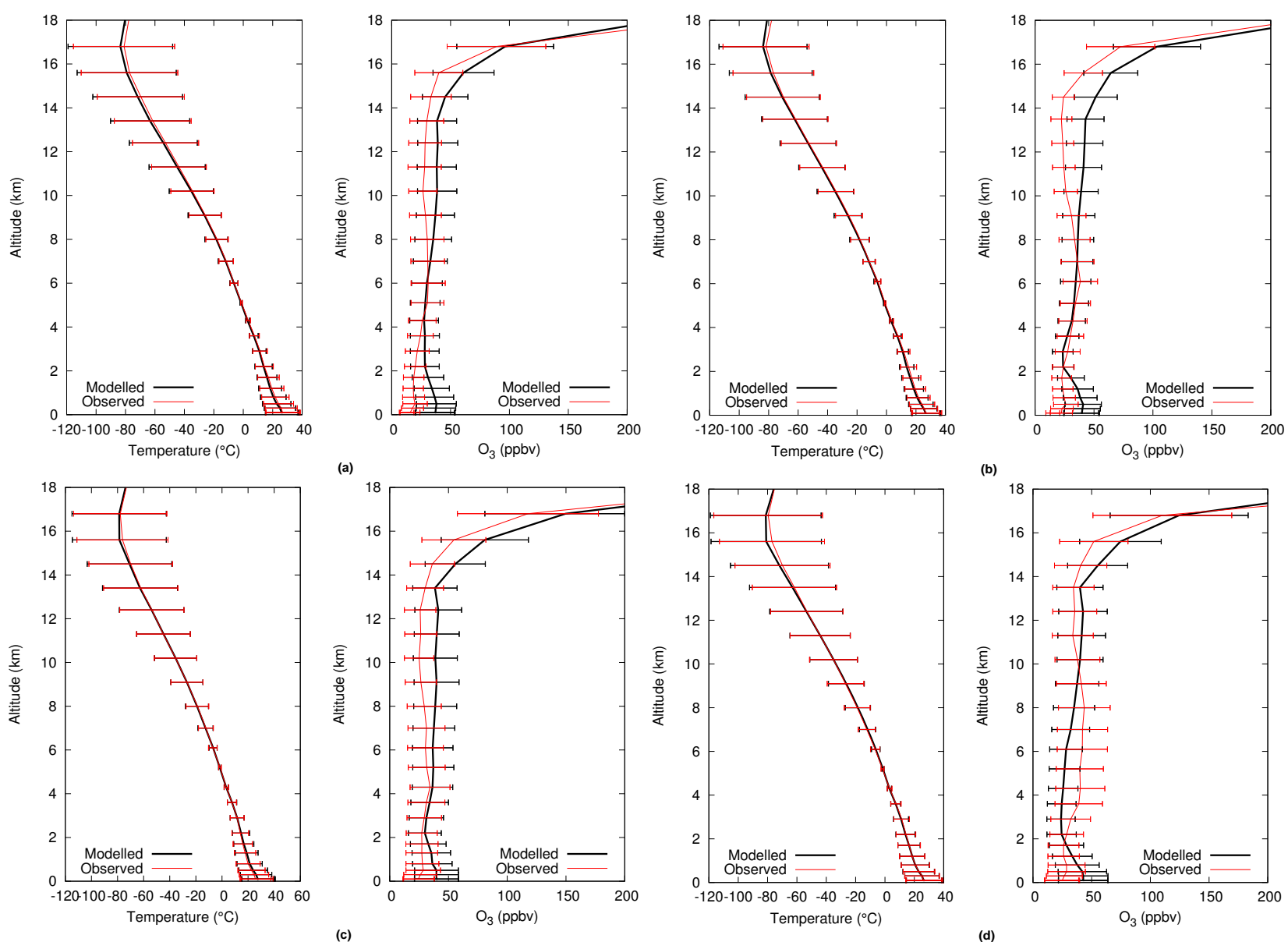

(b)

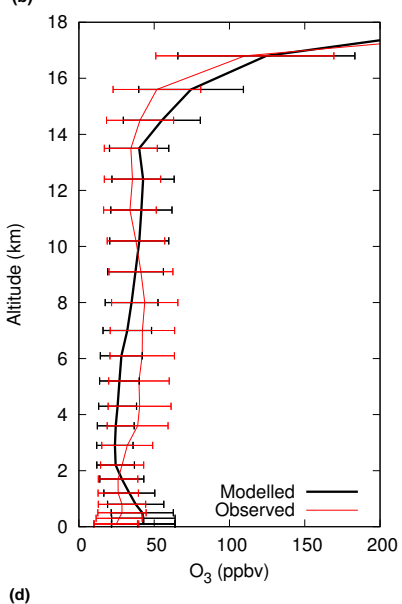

Fig. 2. Seasonally averaged temperature and ozone profiles for South Pacific stations (Fiji, Kuala Lumpur, Samoa and Watukosek), 2001: (a) DJF (b) MAM (c) JJA (d) SON. Horizontal bars represent one standard deviation.

chosen to compare with from the aircraft campaigns are generally not available from satellites. We felt it necessary to consider a general (but not detailed, i.e. with correct meteorological conditions) comparison with aircraft campaigns as it provides an important check on chemical performance of the model.

\section{Modelling approach}

In order to develop an air quality modelling system which can accommodate various scales and processes, we used the GEM model as a computational platform and environmental processes were implemented on-line. Similar implementation of environmental processes is done in WRF/Chem (Weather Research and Forecasting model with Chemistry) (Grell et al., 2005), MC2-AQ (Mesoscale Compressible Community model with Air Quality) (Kaminski et al., 2002), MESSy (Modular Earth Submodel System) (Jöckel et al., 2006), RAMS (Regional Atmospheric Modeling Sys- tem) (Marécal et al., 2006) and Méso-nh (non-hydrostatic mesoscale atmospheric model) (Tulet et al., 2003).

The on-line implementation of environmental processes in the GEM model allows us to run in global uniform, global variable, and limited area configurations, allowing for multiscale chemical weather modelling. This approach provides access to all required dynamics and physics fields for chemistry at every time step. The on-line implementation of chemistry and aerosol processes allows feedback on model dynamics and physics. The use of the GEM framework permits the incorporation of chemical data assimilation techniques into the model validation and application studies in a unified fashion.

The developed modelling system can be used to plan field campaigns, interpret measurements, and provide the capacity for forecasting oxidants, particulate matter and toxics. Also, it can be used to provide guidance to evaluate exposure studies for people, animals, crops and forests, and possibly for epidemiological studies. 

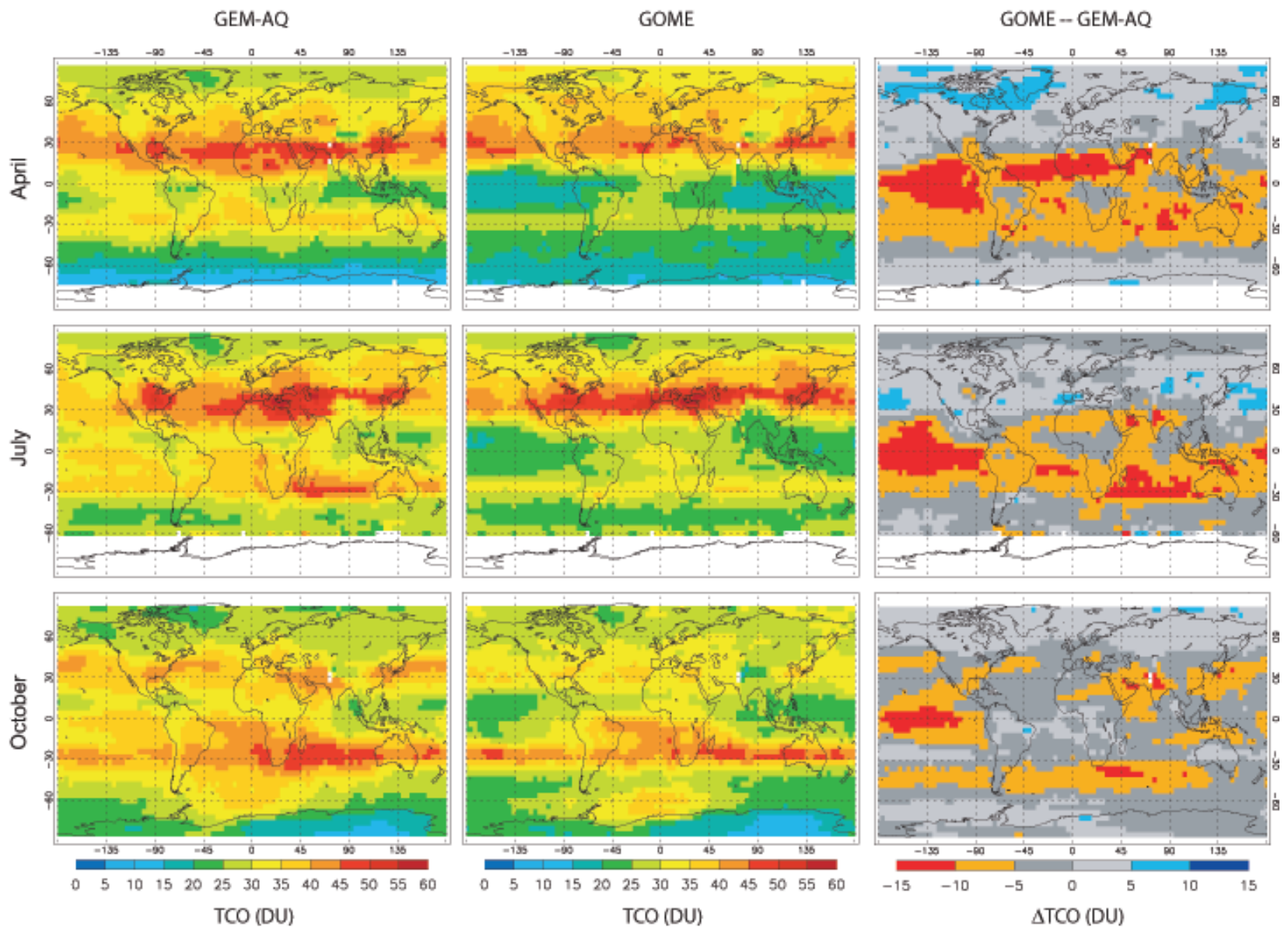

Fig. 3. GEM-AQ, GOME and GOME-GEM differences of tropospheric column ozone for April, July and October, 2001.

\subsection{Host meteorological model}

The host meteorological model used for air quality studies is the Global Environmental Multiscale (GEM) model. GEM can be configured to simulate atmospheric processes over a broad range of scales, from the global scale down to the meso- $\gamma$ scale $(2-20 \mathrm{~km})$.

\subsubsection{Model dynamics}

The set of non-hydrostatic Euler equations (with a switch to revert to the hydrostatic primitive equations) maintains the model's dynamical validity right down to the meso- $\gamma$ scales. The time discretization of the model dynamics is fully implicit, 2 time-level (Côté et al., 1998a,b).

The spatial discretization for the adjustment step employs a staggered Arakawa $\mathrm{C}$ grid that is spatially offset by half a mesh length in the meridional direction with respect to that employed in previous model formulations. The spatial discretization is accurate to second order, whereas the interpolations for the semi-Lagrangian advection are of fourth-order accuracy, except for the trajectory estimation (Yeh et al., 2002). The vertical diffusion of momentum, heat and tracers is a fully implicit scheme based on turbulent kinetic energy (Benoît et al., 1989). GEM version 3.1.2 was used in the current study.

\subsubsection{Model physics}

The physics package consists of a comprehensive set of physical parameterization schemes (Benoît et al., 1989; Mailhot et al., 1989; Mailhot, 1994). Specifically, the planetary boundary layer is based on a prognostic equation for turbulent kinetic energy (Benoît et al., 1989). Shallow convection is simulated using a method described by Mailhot (1994) and is treated as a special case of the turbulent planetary boundary layer to include the saturated case in the absence of precipitation. Over land, in this version, the surface temperature is calculated using the force-restore method (Deardorff, 1978; Benoît et al., 1989) combined with a stratified surface layer. Deep convective processes are handled by a Kuo-type convective parameterization (Kuo, 1974; Mailhot et al., 1989) for the resolutions that we have adopted for this study. Grid scale clouds are produced by the shallow and deep convection parameterizations as well as the 

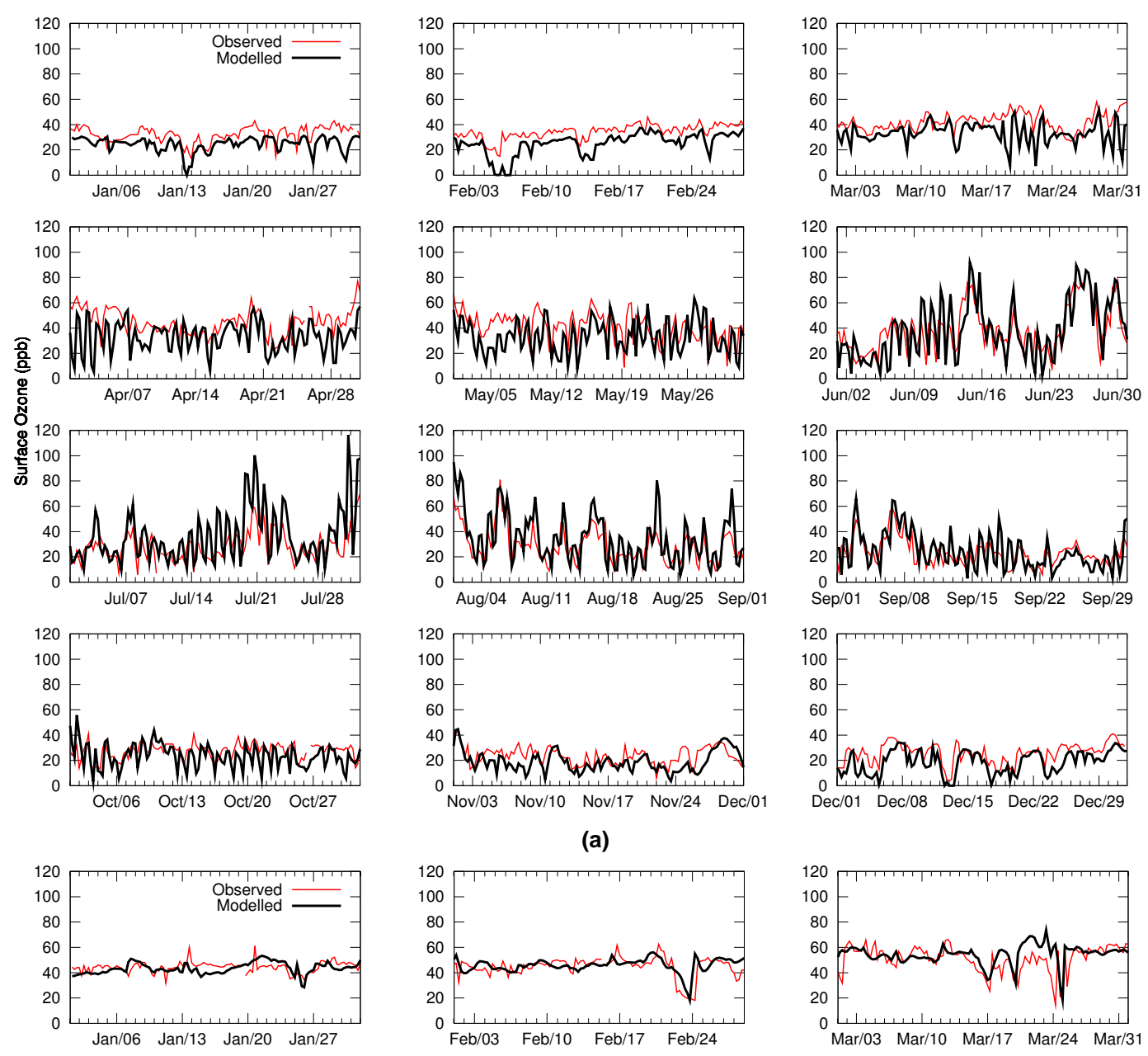

(a)
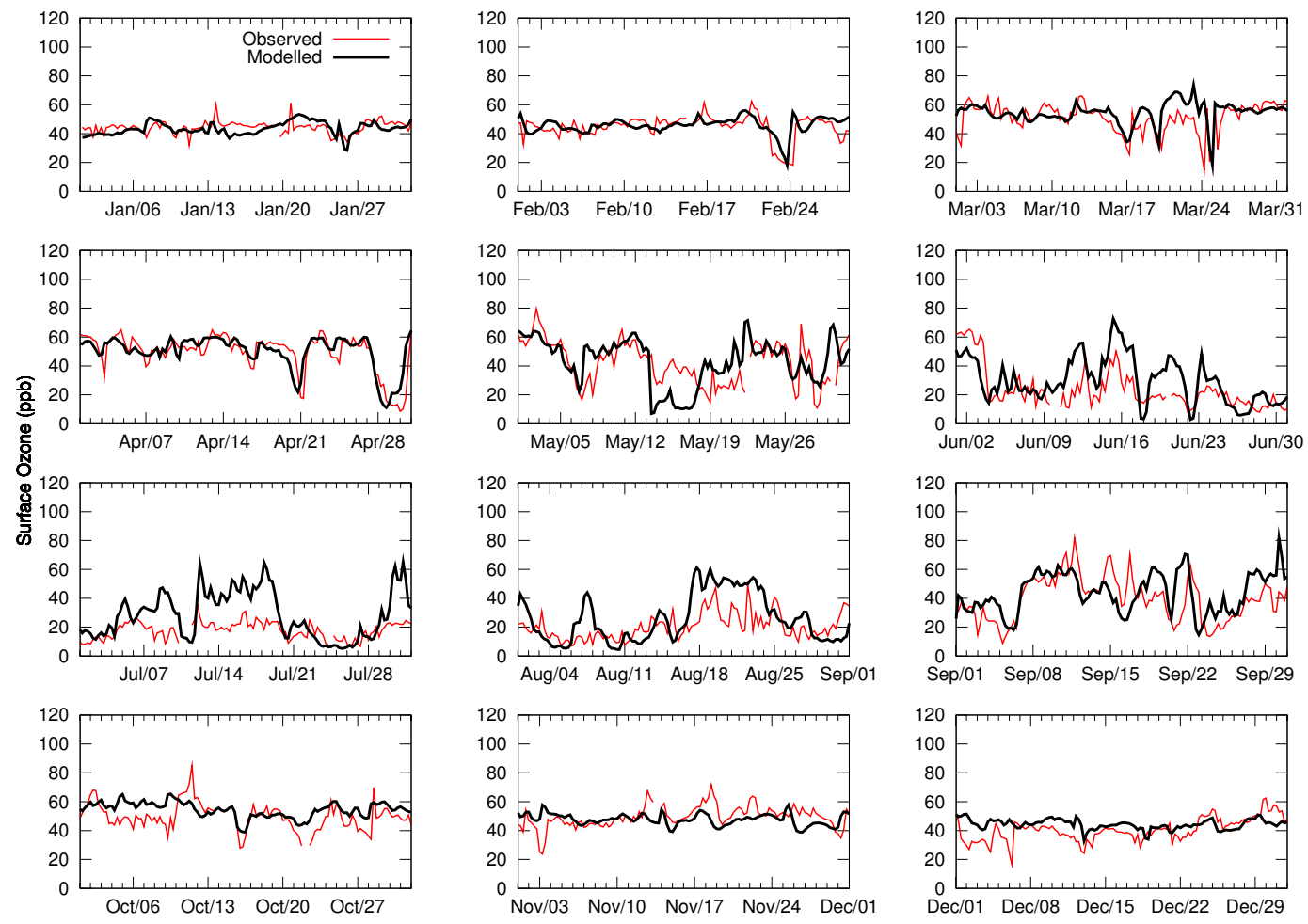

(b)

Fig. 4. 2001 surface ozone time series for Algoma, Canada (a) and Yonagunijima, Japan (b). 

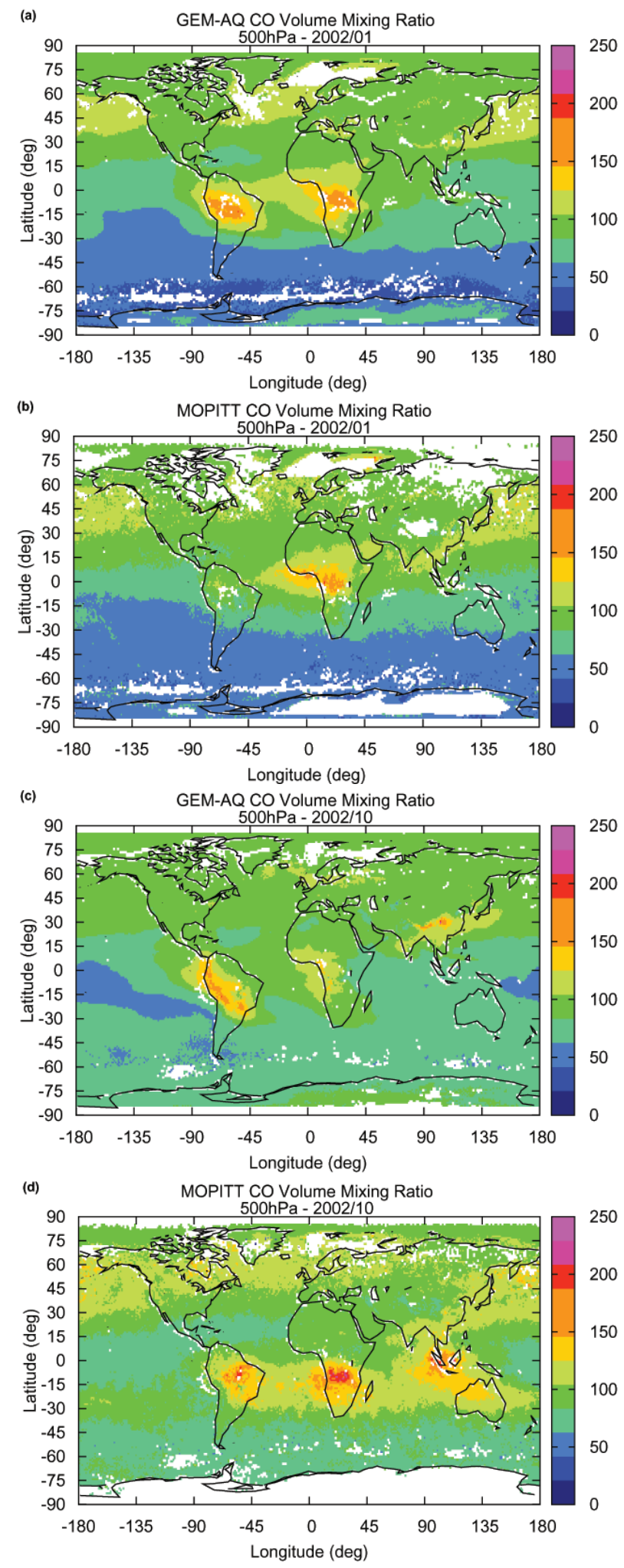

Fig. 5. GEM-AQ and MOPITT CO (ppbv)at $500 \mathrm{hPa}$ for January (a), (b) and October 2002 (c), (d). Only cloud-free pixels are shown. condensation parameterization based on the scheme proposed by Sundqvist $(1978,1981)$ for stratiform clouds. The infrared radiation scheme (Garand, 1983; Garand and Mailhot, 1990; Yu et al., 1997) includes the effects of water vapour, carbon dioxide, ozone, and clouds. The solar radiation scheme follows the method described by Fouquart and Bonnel (1980). Gravity wave drag parameterization is based on a simplified linear theory for vertically propagating gravity waves generated in statically stable flow over mesoscale orographic variations (McFarlane, 1987; McLandress and McFarlane, 1993). GEM physics package version 4.2 was used in the current study.

\subsection{Air quality modules}

Air quality modules are implemented on-line in the host meteorological model. Currently, there are 35 advected and 15 non-advected gas phase species in the model, shown in Table A1. Transport of the chemically active tracers by the resolved circulation is calculated using the semi-Lagrangian advection scheme native to GEM. The vertical transfer of trace species due to subgrid-scale turbulence is parameterized using eddy diffusion calculated by the host meteorological model. Convective transport of chemical tracers is done with the mass flux scheme of Zhang and McFarlane (1995) in this version of GEM-AQ, since the Kuo scheme, from the host meteorological model, is not a mass flux scheme and is not readily adaptable for tracers.

\subsubsection{Gas phase chemistry}

The gas-phase chemistry mechanism currently used in the GEM-AQ model is based on a modification of version two of the Acid Deposition and Oxidants Model (ADOM) (Venkatram et al., 1988), derived from the condensed mechanism of Lurmann et al. (1986). In order to account for background tropospheric chemistry the ADOM-II mechanism has been expanded to include 4 additional species $\left(\mathrm{CH}_{3} \mathrm{OOH}\right.$, $\mathrm{CH}_{3} \mathrm{OH}, \mathrm{CH}_{3} \mathrm{O}_{2}$ and $\left.\mathrm{CH}_{3} \mathrm{CO}_{3} \mathrm{H}\right)$ and 22 reactions. The modified mechanism is comprised of 50 species, 116 chemical and 19 photolysis reactions, and is complemented by a sectional aerosol module with 5 aerosols types. The time evolution of all species is solved using a mass-conserving implicit time stepping discretization, with the solution obtained using Newton's method. Heterogeneous hydrolysis of $\mathrm{N}_{2} \mathrm{O}_{5}$ is calculated using the on-line distribution of aerosol. The list of chemical and photolysis reactions is given in Table A2 and Table A3, respectively.

Although the model meteorology is calculated to $10 \mathrm{hPa}$, the focus of the chemistry is in the troposphere, where species are transported throughout the domain. To avoid the overhead of stratospheric chemistry in this version of the model (a combined stratospheric/tropospheric chemical scheme is currently being developed) we replaced $\mathrm{O}_{3}, \mathrm{NO}$, $\mathrm{NO}_{2}, \mathrm{HNO}_{3}, \mathrm{HNO}_{4}$, and $\mathrm{N}_{2} \mathrm{O}_{5}$ fields with climatologies 
above $100 \mathrm{hPa}$ (6 model levels) after each transport time step. This ensures a reasonable upper boundary while ensuring that the transport of ozone and $\mathrm{NO}_{\mathrm{y}}$ fields to the troposphere is well characterised by the model dynamics. For ozone we used the HALOE (Halogen Occultation Experiment) climatology (e.g. Hervig et al., 1993), while $\mathrm{NO}_{\mathrm{y}}$ fields are taken from CMAM (Canadian Middle Atmosphere Model) (e.g. de Grandpré et al., 2000).

Photolysis rates ( $\mathrm{J}$ values) are calculated on-line at every chemical time step using the method described by Landgraf and Crutzen (1998). In this method, radiative transfer calculations are done using a delta-two stream approximation for 8 spectral intervals in the UV and visible applying precalculated effective absorption cross sections. This method also allows for scattering by cloud droplets and for clouds to be present over a fraction of a grid cell. Both cloud cover and water content are provided by the host meteorological model. The $\mathbf{J}$ value package used, based on the above method, was developed for MESSy (Jöckel et al., 2006) and has been implemented in GEM-AQ.

\subsubsection{Aerosol package}

The current version of GEM-AQ has 5 size-resolved aerosol types, viz. sea salt, sulphate, black carbon, organic carbon and dust. The microphysical processes which describe formation and transformation of aerosols are calculated by a sectional aerosol module (Gong et al., 2003). The particle mass is distributed into 12 logarithmically spaced bins from 0.005 to 10.24 microns radius. This size distribution leads to an additional 60 advected tracers. The following aerosol processes are accounted for in the aerosol module: nucleation, condensation, coagulation, sedimentation and dry deposition, in-cloud oxidation of $\mathrm{SO}_{2}$, in-cloud scavenging, and below-cloud scavenging by rain and snow. The calculated aerosol surface area is used to calculate the reaction rate of the heterogeneous hydrolysis of $\mathrm{N}_{2} \mathrm{O}_{5}$. Results from the aerosol module and GEM-AQ evaluation will be the focus of another study.

\subsubsection{Gas-phase removal processes}

The effects of dry deposition are included as a flux boundary condition in the vertical diffusion equation. Dry deposition velocities are calculated from a 'big leaf' multiple resistance model (Wesely, 1989; Zhang et al., 2002) with aerodynamic, quasi-laminar layer, and surface resistances acting in series. The process assumes 15 land-use types and takes snow cover into account.

GEM-AQ only has a simplified aqueous phase reaction module for oxidation of $\mathrm{SO}_{2}$ to sulphate. Thus, for the gas phase species, wet deposition processes are treated in a simplified way. Only below-cloud scavenging of gas phase species is considered in the model. The efficiency of the rainout is assumed to be proportional to the precipitation rate and
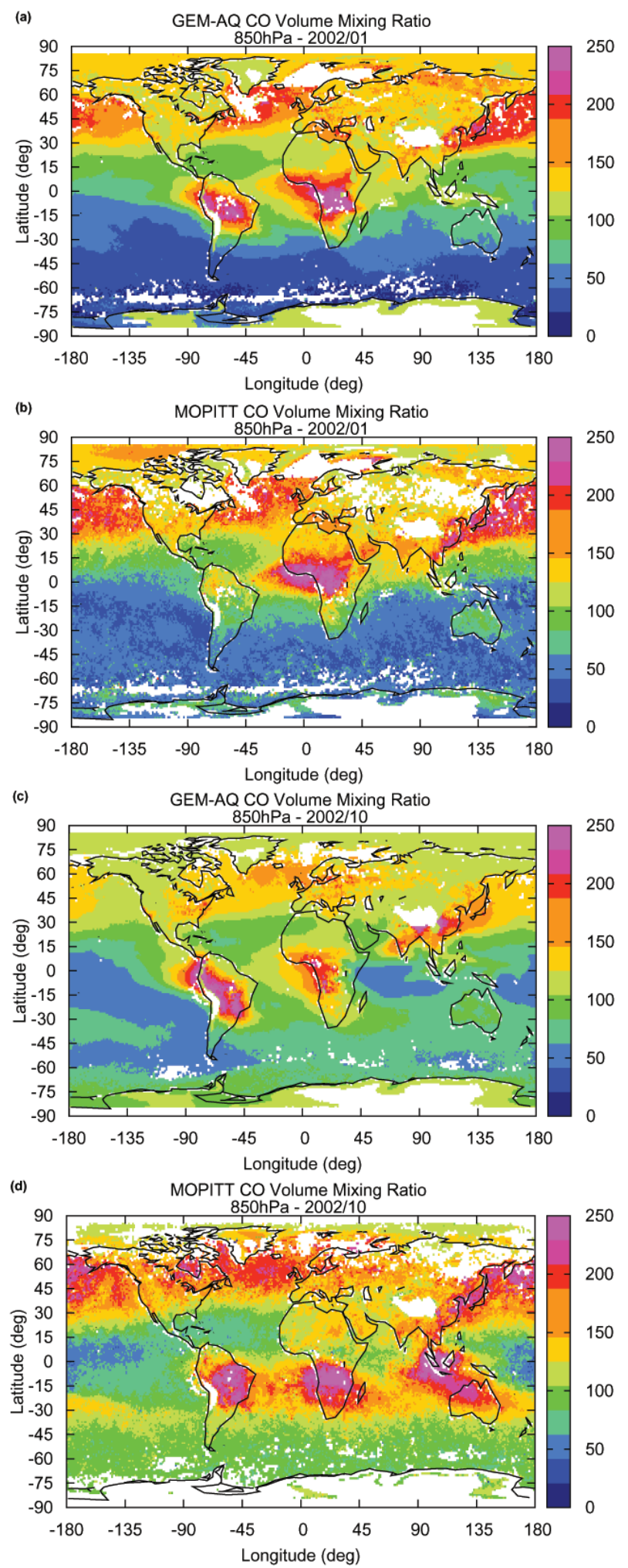

Fig. 6. GEM-AQ and MOPITT CO (ppbv) at $850 \mathrm{hPa}$ for January (a), (b) and October 2002 (c), (d). Only cloud-free pixels are shown. White pixels may also indicate surface pressure $<850 \mathrm{hPa}$. 

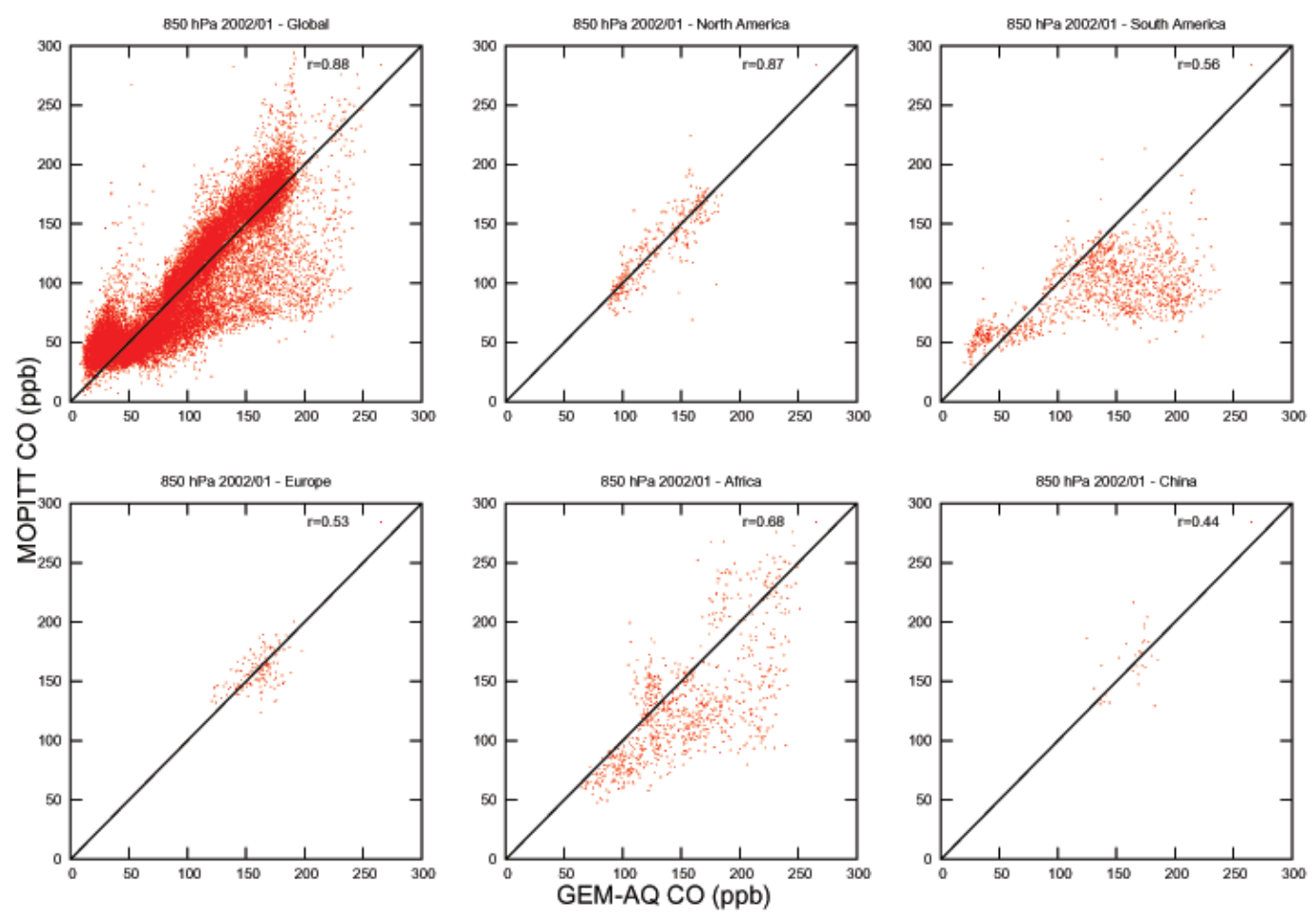

(a)
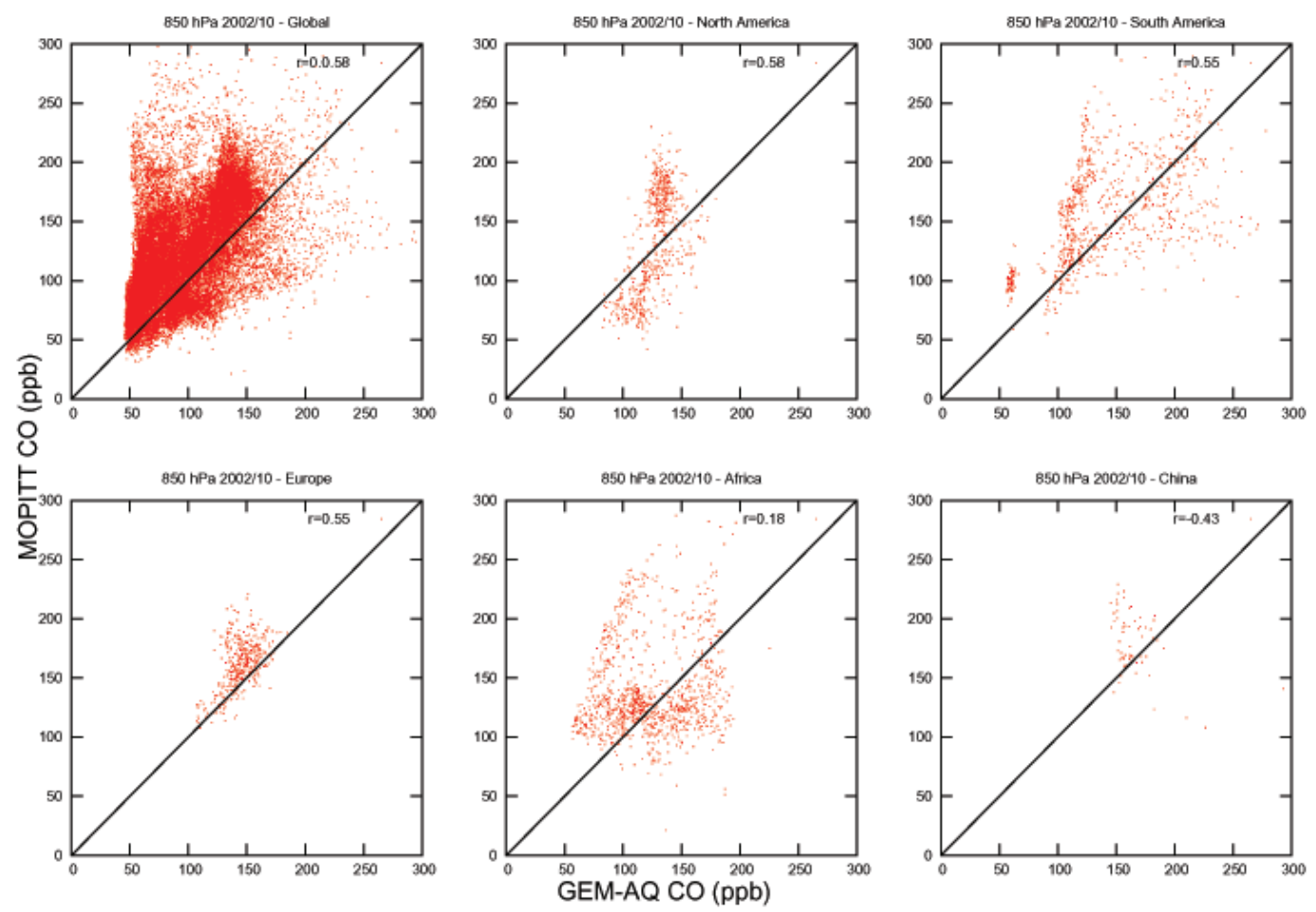

(b)

Fig. 7. GEM-AQ vs. MOPITT CO (ppbv) at $850 \mathrm{hPa}$ correlations for (a) January 2002 and (b) October 2002. Only points where the a priori is $<50 \%$ are shown. 
a species-specific scavenging coefficient. The coefficients applied are the same as those used in the MATCH model (Multiscale Atmospheric Transport and Chemistry Model) used by the Swedish Meteorological and Hydrological Institute (SMHI) (Langner et al., 1998).

\subsubsection{Emissions}

The emission dataset used for global simulations was compiled using EDGAR 2.0 (Emission Database for Global Atmospheric Research, for 1990 base inventory year) and GEIA (Global Emissions Inventory Activity) global inventories (Olivier et al., 1999; Olivier and Berdowski, 2001). The EDGAR 2.0 inventory was chosen for its detailed information on non-methane volatile organic compound speciation. Emission data compiled for GEM-AQ include global fields of anthropogenic emission fluxes with $1^{\circ} \times 1^{\circ}$ resolution and natural emissions with $5^{\circ} \times 5^{\circ}$ resolution. Emission fields were regridded to the model grid and mass flux conservation was ensured. Yearly averaged anthropogenic emissions contain different industrial sectors and non-industrial activity such as burning of agricultural wastes and fuel wood for 14 gaseous pollutants. Monthly averaged biogenic, ocean and soil emission fluxes, as well as biomass burning (forest and savannah) emissions, have been derived for 9 species (7 VOC species, $\mathrm{CO}$ and NO). The various species for which emissions are included, along with source type, viz. anthropogenic combustion, biomass burning, are given in Table A4.

Inter-annual variability of emissions was not considered in the present study. In the upper troposphere/lower stratosphere region (UT/LS) sources of $\mathrm{NO}_{\mathrm{x}}$ are small, from large scale convective updrafts, stratospheric sources, aircraft and lightning. The GEIA inventory for lightning $\mathrm{NO}_{\mathrm{x}}\left(\mathrm{LNO}_{\mathrm{x}}\right)$ emissions gives a global total of $12.2 \mathrm{Tg} / \mathrm{year}$. Previous model simulations of GEM-AQ indicated that inclusion of these levels of $\mathrm{LNO}_{\mathrm{x}}$ produced too much ozone in the UT, which suggested a reduction would be appropriate. This is consistent with the estimate from Schumann and Huntrieser (2007) of 2-8 Tg/year. Based on a qualitative comparison with the SHADOZ ozonesondes we determined that an estimate of $2 \mathrm{Tg} / \mathrm{year}$ would give reasonable results. The monthly mean totals from the GEIA inventory were scaled to give the total of $2 \mathrm{Tg}$ /year. These emissions were placed in the horizontal according to the convective cloud field from the Kuo deep convection parameterization and then distributed in the vertical according to the profiles given in Pickering et al. (1993). These profiles differ for tropical (between $30^{\circ} \mathrm{N}$ and $30^{\circ} \mathrm{S}$ ) marine and continental grid points and midlatitude grid points. One weakness of this method is that the intensity of the convection is not taken into account. Storms over continents produce more lightning than over the ocean, resulting in an excess of emissions over the oceans and not enough over the continents. No aircraft emissions were used in the present simulations.
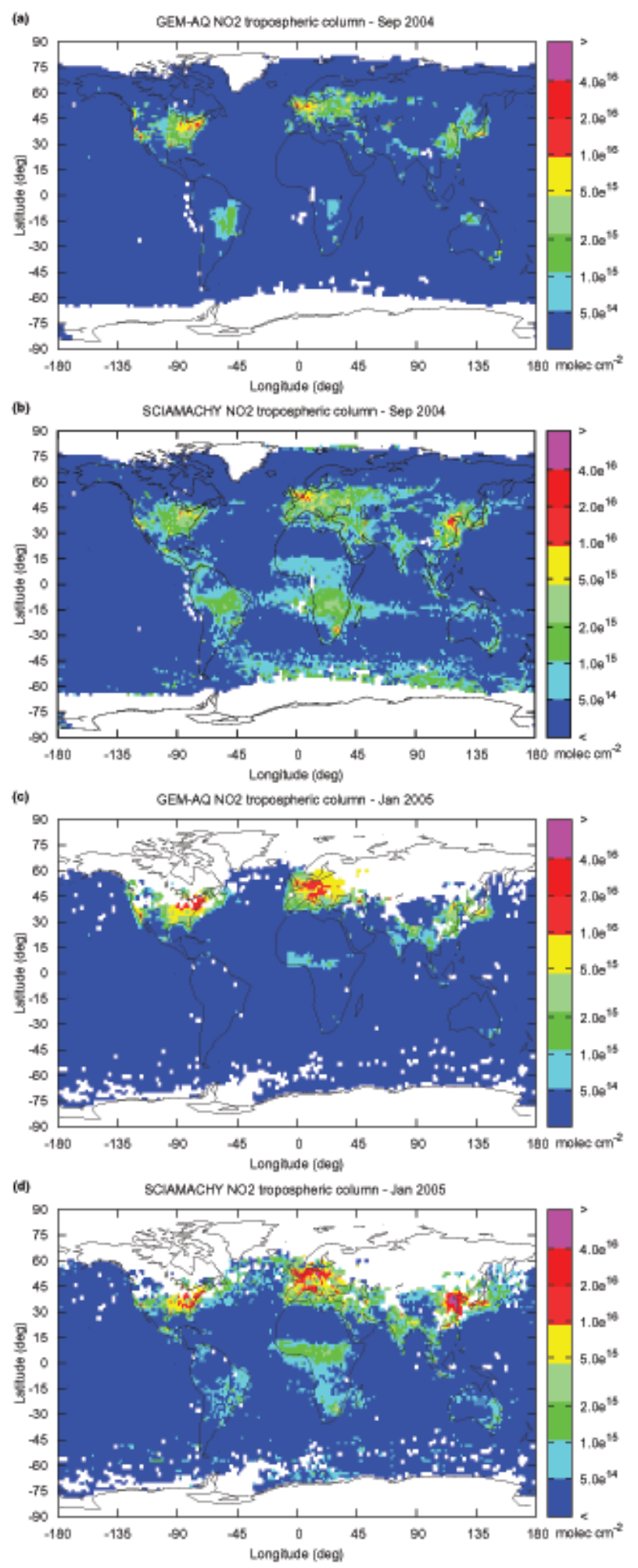

Fig. 8. September 2004 tropospheric $\mathrm{NO}_{2}$ column from (a) GEMAQ using the subtraction of the Pacific sector and (b) SCIAMACHY. Figures (c) and (d) are for January 2005. 

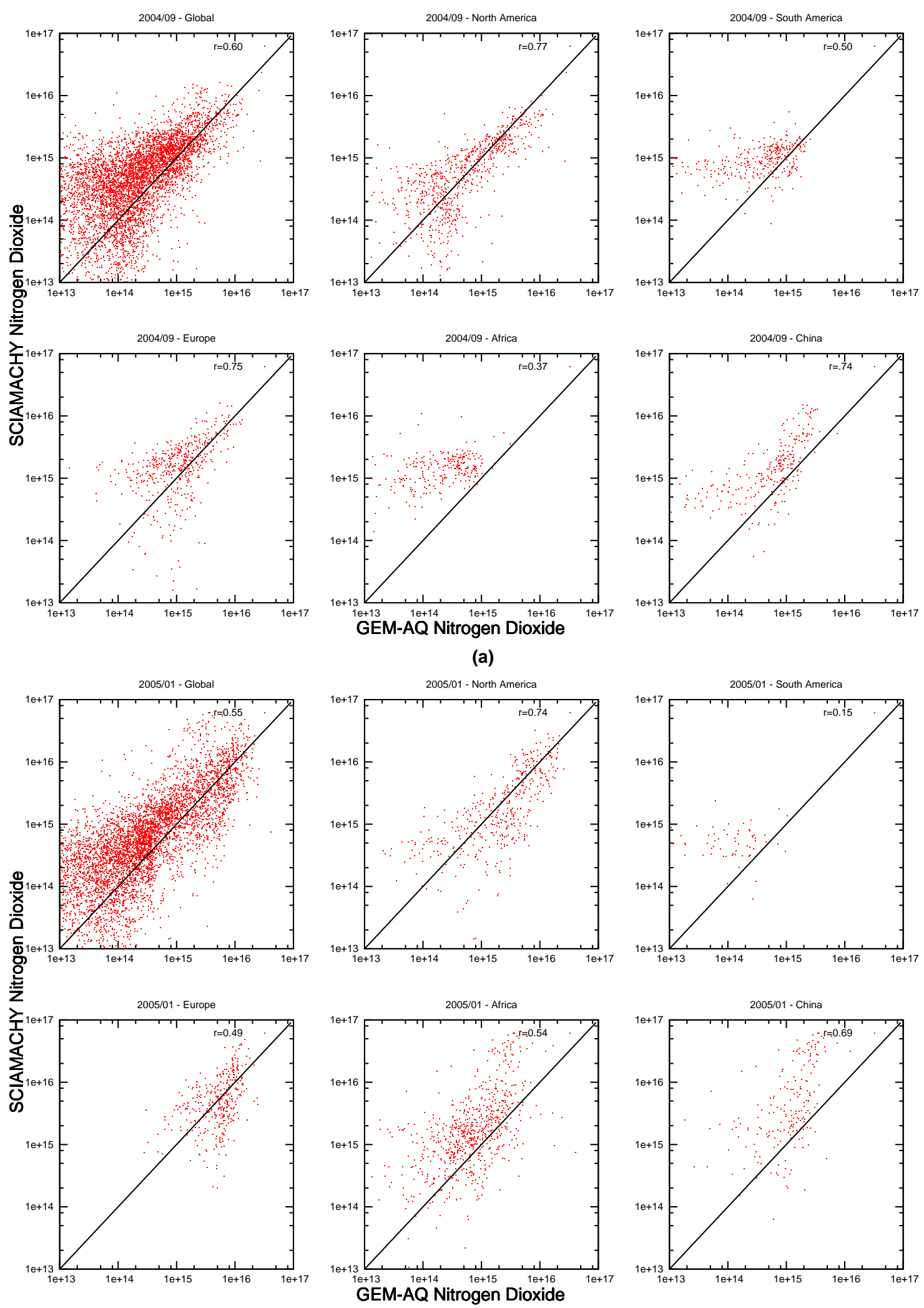

(b)

Fig. 9. GEM-AQ vs. SCIAMACHY tropospheric $\mathrm{NO}_{2}$ column correlations for (a) September 2004 and (b) January 2005. 

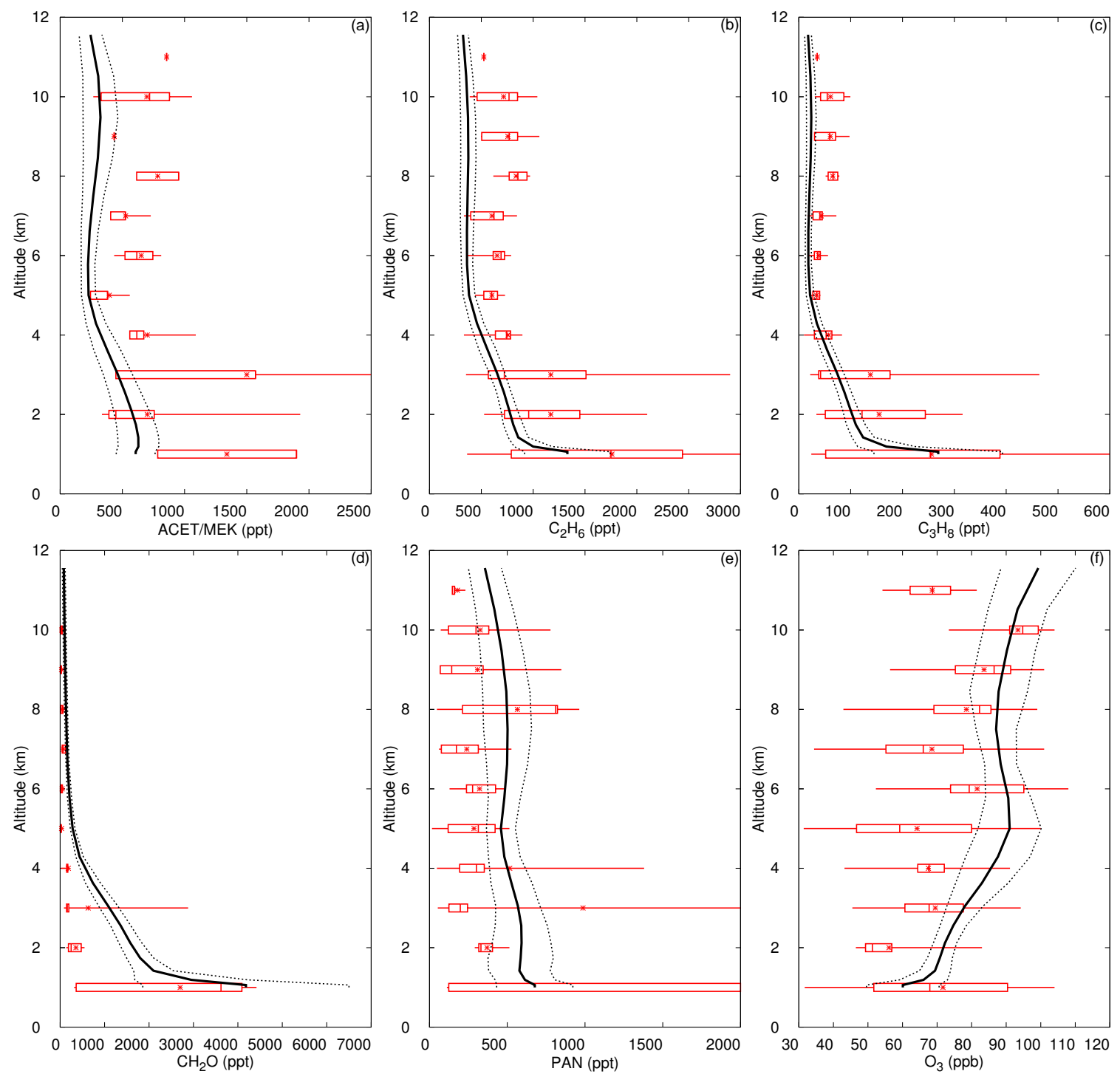

Fig. 10. Seasonally averaged profiles from TRACE-A (21 September-26 October 1992) (shown in red) and GEM-AQ (shown in black) for the same period in 2001 .

\section{Model simulation and results}

For the simulations carried out in the current study, the model was configured with 28 hybrid vertical levels (Laprise and Girard, 1990) with the model top at $10 \mathrm{hPa}$. A sponge layer is present to prevent reflected waves at the top of the model and acts on the top model level.

The horizontal model grid was set as non-rotated uniformresolution latitude-longitude mesh with a grid spacing of $1.5^{\circ}$, resulting in 240 by 120 grid points on a sphere. The model time step was set to 1800 seconds for dynamics, physics and air quality processes. Meteorological initial conditions were taken from the Canadian Meteorological Centre global assimilation system (Gauthier et al., 1999, 2007; Laroche et al., 2007). The GEM-AQ model was run in $24 \mathrm{~h}$ forecast segments starting from 6-h trial fields generated in a separate GEM execution. This setup resulted in meteorological fields being forced to observations once a day.

The chemical initial conditions used to initiate the model for the first time were generated from several sources. Chemical fields in the upper troposphere and lower stratosphere were taken from the CMAM model (de Grandpré et al., 2000) for January. In order to create a balanced and realistic chemical state, GEM-AQ was spun up for 6 months starting from July 1, 2000. This initial period was not used in the analysis of model results. In addition, a number of fields and parameters are needed to specify surface characteristics. These were obtained from analysed monthly climatological and geophysical datasets and include surface roughness, land-sea mask, albedo, deep soil temperature, ice cover, and topogra- 

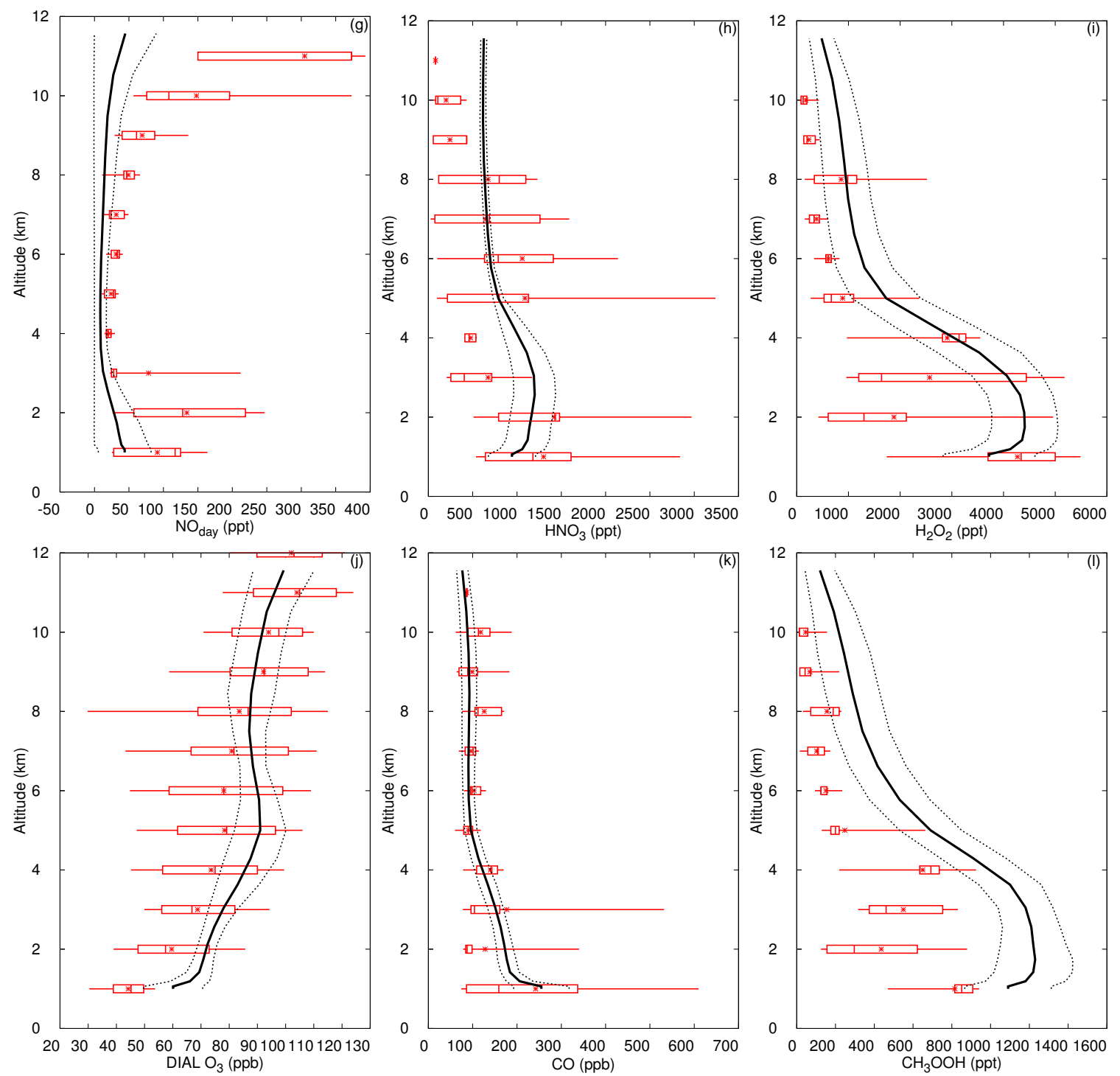

Fig. 10. Continued.

phy. The surface roughness length is influenced by topography, land use, snow and ice cover. Climatological fields are monthly, but they do not vary from year to year. Also, we use assimilated sea surface temperature in the model.

\subsection{Ozone}

One of the basic species which drives tropospheric chemistry is ozone and so it is essential for a model to provide a reasonable spatial and temporal representation of the 3-D ozone field. Thus we have compared seasonally averaged GEM-AQ model ozone profiles from 2001-2005 with ozonesonde data compiled by Logan (1999) for the 1980s and 1990s.

The comparison of ozonesondes with model results consistently shows good agreement with the observations, although the region between 300 and $100 \mathrm{hPa}$ tends to be under-predicted in most areas of the globe for all seasons. This height range is where the ozonesonde measurements show the most variability. Interestingly, we have found that use of sigma coordinates caused an excess of ozone influx in regions of high topography, such as over the Himalayas and Greenland. This resulted in too much upper tropospheric ozone in the northern hemisphere. Changing to the hybrid coordinate reduced the flux. Figure 1 shows seasonally averaged vertical profiles for two stations, Churchill $\left(59^{\circ} \mathrm{N}\right.$, $\left.94^{\circ} \mathrm{W}\right)$ and Hohenpeissenberg $\left(48^{\circ} \mathrm{N}, 11^{\circ} \mathrm{E}\right)$.

In general, the agreement with all the stations is quite similar. Some ozonesonde stations show a summer model overprediction in the lowest levels. This may be due to the dilution of emissions over relatively large grid squares where ozone production is more efficient at lower mixing ratios (Liu et al., 1987). 
To examine the model performance in the tropics where deep convection and lightning play a role in the distribution of ozone, the SHADOZ dataset (Thompson et al., 2003a,b) was used. Figure 2 shows a comparison of seasonally averaged SHADOZ temperature and ozonesondes measurements at four stations in the South Pacific with GEM-AQ results for 2001. There is an over-prediction in this region, likely due to an incorrect diagnosis of deep convective cloud, and therefore the generation of ozone from lightning generated $\mathrm{NO}_{\mathrm{x}}$ is not captured correctly. The individual ozonesonde profiles (not shown here) indicate that this may be the case.

Comparison with ozonesondes gives detailed vertical resolution, but over a limited spatial region. Another method to evaluate the model is to compare ozone data with more limited vertical resolution but much more comprehensive horizontal spatial coverage. For this aspect of the study we have compared model results with tropospheric ozone columns from GOME, a nadir viewing instrument on ESA's ERS2 satellite. GOME tropospheric data have been validated against contemporaneous ozonesonde data (Liu et al., 2005, 2006).

Both GOME and GEM-AQ tropospheric columns are calculated using a tropopause determined by combining the dynamic tropopause in the extratropics and the thermal tropopause near the equator (Liu et al., 2006). In order to account for the different spatial resolutions of the GOME ( 960 by $80 \mathrm{~km}$ ) retrievals and GEM-AQ runs, model output profiles corresponding to the model grid cells overlapping each GOME pixel were interpolated onto the GOME vertical levels, then averaged using the relative surface area of the corresponding GOME pixel and the GEM-AQ cell intersection as a weight. The model was sampled within 3 hours of the GOME observing time. The GOME averaging kernel was then applied to the averaged model profile, and the tropospheric column calculated by integrating the transformed profile up to the tropopause level. Finally, all the column data (GOME and model) were mapped onto the model grid by the same area-weighting method, and the monthly means obtained.

Figure 3 shows the GEM-AQ, GOME and GOME-GEM differences in tropospheric ozone column for April, July and October, 2001. In April, GEM-AQ under-predicts in the high northern latitudes $\left(>30^{\circ} \mathrm{N}\right)$ with differences of 5$10 \mathrm{DU}(<20 \%)$. This agrees with the comparison with the ozonesondes. In the tropical ocean regions, GEM-AQ has ozone columns as large as $15 \mathrm{DU}$ (about $80 \%$ ) too large compared with GOME. This is consistent with the results compared with SHADOZ. For southern latitudes GEM-AQ has differences less than $10 \mathrm{DU}$ (overprediction $<40 \%$ and underprediction $<20 \%$ ). For July the pattern is much the same, although a plume off the coast of China is not captured by the model. For October, GEM-AQ over-predicts by 5-10 DU (up to $30 \%$ ) over most of the globe. Only over the southern Pacific does the disagreement reach $15 \mathrm{DU}$ (about 60\%). This might be because GEM-AQ is not capturing the timing and distribution of $\mathrm{NO}_{\mathrm{x}}$ generation by lightning, as mentioned above. The method that we have adopted relies on the modelled deep convective cloud, which may put too much $\mathrm{NO}_{\mathrm{x}}$ over the ocean.

Many of the important processes involved in the study of air quality take place near the surface. Surface data gathered from the World Data Centre for Greenhouse Gases (http: //gaw.kishou.go.jp/wdegg.html) provides an opportunity to analyse the model's performance in detail. Figure 4 shows 6 hourly surface ozone data from two stations, Algoma $\left(47^{\circ} \mathrm{N}\right.$, $\left.84^{\circ} \mathrm{W}\right)$ and Yonagunijima $\left(24^{\circ} \mathrm{N}, 123^{\circ} \mathrm{E}\right)$ for 2001 . The agreement for the Japanese station is quite good. Generally, the model captures the background levels. Many of the excursions from the background are captured, such as in late February, April and the general elevation of the background in September. However, there are some occurrences of plumes not shown in the measurements, and some elevated values are modelled too high. For the Canadian station chosen the agreement between measurements and model is quite acceptable. The episodes in June and July and much of the variability of the measurements are captured.

\subsection{Carbon monoxide}

The main source of carbon monoxide in the atmosphere is from oxidation of hydrocarbons while primary emissions, from incomplete combustion, contribute less than half of the total source (Shindell et al., 2006). Carbon monoxide has a chemical lifetime of a few months or longer in the troposphere, depending on latitude and season. It can be a very useful tracer of the resolved transport, but is also impacted, of course, by large scale convection and transport in the planetary boundary layer. Thus, a comparison with observations serves as a useful diagnostic of both transport and emissions in the model. In the following section we compare monthly averaged model results with the $\mathrm{CO}$ monthly averaged level 3 data from the MOPITT instrument (Drummond, 1992; Drummond and Mand, 1996) on the NASA Terra satellite. MOPITT is a nadir viewing instrument and, like GOME, has limited vertical resolution and is most sensitive at about $500 \mathrm{hPa}$. For this study we compare with the $\mathrm{CO}$ volume mixing ratio data obtained from the MOPITT instrument for 500 and $850 \mathrm{hPa}$. The MOPITT kernel has been applied to the GEM-AQ data.

Figure 5 shows the $500 \mathrm{hPa}$ data for January and October, 2002 for GEM-AQ and MOPITT. To generate these figures, all the points were used regardless of the contribution from the a priori. For most times of the year, GEM-AQ captures the general pattern of the measured CO quite well. In January there is good agreement between GEM-AQ and MOPITT data at $500 \mathrm{hPa}$, except over South America, where GEMAQ over-predicts. The emissions in this region do not look excessive, but January is a period of strong convection in this region and the model may be transporting too much $\mathrm{CO}$ to the higher levels. 
In October, GEM-AQ completely misses the heavy biomass burning that occurred over Indonesia (Edwards et al., 2006) since it uses climatological emissions. In the Southern Hemisphere the signal from biomass burning over southern Africa is too small compared to MOPITT data. In the northern hemisphere, the GEM-AQ results are mostly a priori, which gives less variability than if the kernel was not applied to the model data.

Figure 6 shows the MOPITT CO mixing ratios for the $850 \mathrm{hPa}$ level for the same months as Fig. 5. Because of the shape of the kernel functions, we note that the results for $850 \mathrm{hPa}$ are strongly influenced by the 700 to $500 \mathrm{hPa}$ region. This gives the impression that the surface emissions were shifted south in Africa, but when the kernel is not applied to the model data, the strong signal from emissions in west Africa can be seen where it is expected. The kernel also increases the GEM-AQ CO levels over Amazonia due to the influence of the higher levels.

For October, the $850 \mathrm{hPa}$ GEM-AQ CO mixing ratios are too low by about $20 \%$. In particular, $\mathrm{CO}$ values are low over the northeast coast of China and Indonesia and most of the southern subtropics except for Amazonia.

Figure 7 shows the correlation diagrams for the same months at $850 \mathrm{hPa}$, using only points where the a priori is less than $50 \%$. The regions noted are continental only, except for the global region, which is the entire domain. These plots confirm the overall good agreement between the model and MOPITT observations for January and the marginal agreement for October.

\subsection{Nitrogen dioxide}

The $\mathrm{NO}_{\mathrm{x}}$ family is important for the generation of ozone in the troposphere. It has a relatively short lifetime (less than a week), so it is closely linked to emission sources. NO and $\mathrm{NO}_{2}$ are closely related and the daytime ratio of $\mathrm{NO}$ to $\mathrm{NO}_{2}$ rapidly increases with height in the troposphere, so that most of the $\mathrm{NO}_{2}$ is concentrated in the first few kilometres. These characteristics allow the retrieval of $\mathrm{NO}_{\mathrm{x}}$ emissions from space (Martin et al., 2006). The SCIAMACHY instrument (Burrows et al., 1995; Bovensmann et al., 1999) on ESA's Envisat performs measurements in the UV-vis and near IR using solar occultation, limb viewing of scattered light and also observation of scattered light in the nadir direction. In the latter mode it is similar to GOME but has a higher horizontal spatial resolution (typically $60 \mathrm{~km} \times 30 \mathrm{~km}$ ).

In this section we compare the $\mathrm{NO}_{2}$ tropospheric column measurements from SCIAMACHY with the GEM-AQ column $\mathrm{NO}_{2}$. Tropospheric $\mathrm{NO}_{2}$ columns are retrieved from measurements of SCIAMACHY in three steps. First, the total absorption of NO2 along the light path (slant column) is determined using the differential optical absorption spectroscopy (DOAS) method. In the second step, the stratospheric component of the $\mathrm{NO}_{2}$ is removed by subtracting the signal over the clean Pacific sector. Finally, the light path is accounted for by application of airmass factors based on a priori assumptions and radiative transfer modelling and a vertical tropospheric column is calculated. Details on the retrieval and the assumptions made can be found in Richter et al. (2005). To be consistent, $\mathrm{NO}_{2}$ over the Pacific sector was also subtracted from the GEM-AQ results, although the stratospheric fields are from climatology as described earlier. As a result, possible errors introduced in the satellite data from longitudinal variations in stratospheric $\mathrm{NO}_{2}$ are not reproduced in the model data.

In Fig. 8 we present GEM-AQ and SCIAMACHY column data for September 2004 and January 2005 using a logarithmic scale because of the large variability of tropospheric $\mathrm{NO}_{2}$. The SCIAMACHY tropospheric column was computed by subtracting the total column over a clean reference sector in the Pacific, between $180^{\circ}$ and $220^{\circ} \mathrm{E}$. This column is assumed to be the stratospheric contribution only. For comparison with GEM-AQ, the SCIAMACHY data is shown on the same $1.5^{\circ} \times 1.5^{\circ}$ grid. For the GEM-AQ results (sampled within $30 \mathrm{~min}$ of satellite overpass), the same clean reference sector method was used. The tropospheric column was also computed using the thermal tropopause and was found to be about $25 \%$ higher than the clean sector method in relatively unpolluted regions and through the tropics. This may suggest the reference sector in GEM-AQ has an excess of tropospheric $\mathrm{NO}_{2}$, perhaps from lightning emissions. Martin et al. (2002), also show non-zero tropospheric columns of $\mathrm{NO}_{2}$ in their model simulation over Pacific.

In Fig. 8, over North America and Europe, where anthropogenic emissions dominate, the agreement is good for both September and January. However, column $\mathrm{NO}_{2}$ over China is underestimated by an order of magnitude in January 2005 and to a lesser extent in September 2004. We note that emissions over China have significantly increased since 1990 (EDGAR inventory year). This can be seen from the satellite data (Richter et al., 2005) and also from bottom-up estimates (Zhang et al., 2007) In Africa and South America, the values are generally underestimated. In this region, using the thermal tropopause to determine the column gives better agreement. Again, this is probably due to an excess of lightning $\mathrm{NO}_{\mathrm{x}}$ in the reference sector. In January, a low density plume can be seen from North America over the Atlantic by both the model and observations.

Figure 9 presents correlation diagrams between SCIAMACHY and GEM-AQ for September 2004 and January 2005 for the entire domain (globe) and for North America, South America, Europe, Africa and China, for which only data points over the continental surfaces were selected. The large scatter for low columns is not surprising, as the random noise in the SCIAMACHY $\mathrm{NO}_{2}$ measurements is of the order of $5 \times 10^{14}$ molecules $/ \mathrm{cm}^{2}$ standard deviation for individual measurements. In addition, there are uncertainties in the airmass factor which are largely multiplicative and are 40 to $60 \%$ over polluted regions. 
For September and January the global picture is that SCIAMACHY $\mathrm{NO}_{2}$ columns are relatively high compared to GEM-AQ. At the low end of mixing ratios there is more variability, as might be expected. A perusal of the individual regions reveals the source of the bias. For China and Africa, both January and September exhibit strong biases for $\mathrm{NO}_{2}$ columns above about $1-2 \times 10^{15}$ molecules $/ \mathrm{cm}^{2}$ but for smaller columns there is relatively good agreement. It can be noted that the SCIAMACHY values for South America have a smaller variability than the GEM-AQ values. For North America there is quite good agreement. The bias over Africa is reduced when the $\mathrm{NO}_{2}$ tropospheric column is computed using the thermal tropopause rather than the clean sector method. This is not the case over China, indicating the anthropogenic emissions used in the simulation may be too low. GOME and SCIAMACHY see a 50\% increase in $\mathrm{NO}_{2}$ columns over Eastern China in the period 1996-2004 (Richter et al., 2005).

\subsection{Other species}

Global coverage of species other than $\mathrm{O}_{3}, \mathrm{NO}_{2}$ and $\mathrm{CO}$ is not as readily available. However, aircraft campaigns can provide a local but comprehensive chemical picture of the troposphere. While the aircraft campaigns are for a specific weather situation not covered by our simulation, they are still useful. We have addressed specific weather situations covering boreal forest burning in Quebec (O'Neill et al., 2006) and air quality in the recent European heat wave (Struzewska and Kaminski, 2008). Nevertheless, to assess some of the other species in the model we have made a comparison with the chemical measurements of the TRACE-A campaign during 1992 (Fishman et al., 1996). Clearly, since the years are quite different, we do not expect the same degree of agreement as one would aim for in a comparison of that specific time period. However, we do compare observations taken during TRACE-A from 21 September to 26 October 1992 with model results for the same period in 2001 so that the same general weather features might be present.

The results, averaged over the whole period for $\mathrm{CH}_{3} \mathrm{CHO}$, $\mathrm{C}_{2} \mathrm{H}_{6}, \mathrm{C}_{3} \mathrm{H}_{8}, \mathrm{CH}_{2} \mathrm{O}, \mathrm{PAN}, \mathrm{O}_{3}, \mathrm{NO}, \mathrm{HNO}_{3}, \mathrm{H}_{2} \mathrm{O}_{2}$, DIAL O $\mathrm{O}_{3}$, $\mathrm{CO}$ and $\mathrm{CH}_{3} \mathrm{OOH}$ are shown in Fig. 10a to 1, respectively. The focus of the TRACE-A campaign was to study the cause and source of high concentrations of ozone over the tropical Atlantic Ocean between southern Africa and South America. This season is a period of intense burning of vegetation, resulting in high concentrations of ozone in this region. We note that 1992 was an extreme year for biomass burning, as shown by Schultz et al. (2008). Overall, the averaged results during the period compare well for all species, including $\mathrm{CO}$ and hydrocarbons, considering that climatological emissions were used. The variability of the measurements is not seen in the model because of this, and values are slightly underpredicted. Too much methyl peroxide $\left(\mathrm{CH}_{3} \mathrm{OOH}\right)$ in the lowest layers and relatively good agreement of $\mathrm{H}_{2} \mathrm{O}_{2}$ might in- dicate that the convective transport modelled is insufficient during this period, as $\mathrm{CH}_{3} \mathrm{OOH}$ is less soluble than $\mathrm{H}_{2} \mathrm{O}_{2}$ and is able to be transported into the upper troposphere. The observed NO profile shown in Fig. $10 \mathrm{~g}$ has the "c" shape that is associated with $\mathrm{NO}_{\mathrm{x}}$ from convection, while the model profile is not as clearly defined. This would indicate that there is insufficient convective transport and $\mathrm{LNO}_{\mathrm{x}}$ generation in the model.

\subsection{Model metrics}

One of the means of characterising the general properties of an atmospheric model is via its $\mathrm{OH}$ oxidation capacity, and for this two gases are generally useful, $\mathrm{CH}_{4}$ and $\mathrm{CH}_{3} \mathrm{CCl}_{3}$ as their lifetimes can be characterised by other means. We have calculated their global chemical lifetimes, $\tau_{i}$, using $\tau_{i}=\int n_{i} d z / \int k_{\mathrm{OH}}^{i} n_{i}[\mathrm{OH}] d z$ (averaged over a year) where $n_{i}$ and $[\mathrm{OH}]$ represent the number densities of either $\mathrm{CH}_{4}$ or $\mathrm{CH}_{3} \mathrm{CCl}_{3}$ and $\mathrm{OH}$, respectively and $k_{\mathrm{OH}}^{i}$ is the loss rate for the species with $\mathrm{OH}$. Using the rate data from Sander et al. (2006) we find $\tau_{\mathrm{CH}_{4}}=7.7$ years and $\tau_{\mathrm{CH}_{3} \mathrm{CCl}_{3}}=4.6$ years using tropospheric $\mathrm{OH}$ (below $100 \mathrm{hPa}$ ). These values are reduced to 7.0 years and 4.2 years when using total atmospheric OH. The IPCC report (IPCC, 2001) gives a lifetime of 9.6 years for $\mathrm{CH}_{4}$ (8.4 years including stratospheric and soil losses) and 5.7 years for $\mathrm{CH}_{3} \mathrm{CCl}_{3}$. In a multi-model study, Stevenson et al. (2006) found $\mathrm{CH}_{4}$ lifetimes ranging from 7.5 to 10 years.

Another important metric for a tropospheric model is the ozone budget. Based on a $4^{\circ} \times 4^{\circ}$ simulation for the year 2001 we have calculated the global tropospheric ozone budget in GEM-AQ and compared it with results from Stevenson et al. (2006). In order to make the comparison consistent, we defined our troposphere in the same way as in the aforementioned study, i.e., the region where monthly mean ozone is $<150 \mathrm{ppb}$. The net chemical production thus calculated is $417 \mathrm{Tg}\left(\mathrm{O}_{3}\right) / \mathrm{yr}$ (compare with $442 \pm 309$ in the multi-model study), the dry deposition is $815 \mathrm{Tg}\left(\mathrm{O}_{3}\right) / \mathrm{yr}$ (compared with $1003 \pm 200$ ), and the burden is $384 \mathrm{Tg}\left(\mathrm{O}_{3}\right)$ (compare with $344 \pm 39)$. The stratospheric influx of ozone, based on balancing the loss and production terms, is estimated to be $398 \mathrm{Tg}$ (compare with 552 \pm 168 ). Observed correlations with other gases suggest a stratospheric influx of about $475 \mathrm{Tg}\left(\mathrm{O}_{3}\right) / \mathrm{yr}$ (Murphy and Fahey, 1994; McLinden et al., 2000).

\section{Discussion and conclusions}

In this study we have focused on the large scale properties of the presented modelling system. This limited comparison indicates that GEM-AQ is, in general, able to capture the spatial details of the chemical fields in the middle and lower troposphere. The comparison with GOME and SHADOZ shows the largest discrepancy over the tropical oceans. Some of the problem may be due to our treatment 
of deep convection and resulting lightning $\mathrm{NO}_{\mathrm{x}}$ emissions. A more detailed study of the modelled convective activity is under way. Other limitations may be due to the use of seasonally averaged biomass burning emissions. We have developed an emission system for boreal and tropical fires based on monthly biomass burning emissions at $1^{\circ} \times 1^{\circ}$ spatial resolution for year 2004 from the Global Fire Emission Database version 2 (GFEDv2) but distributed into hourly emissions using fire counts from the Geostationary Operational Environmental Satellite (GOES) Wild Fire Automated Biomass Burning Algorithm (WF_ABBA) fire product as weighting factors (Lupu et al., $2008^{1}$ ). This work also showed sensitivity to the height distribution of emissions. For the simulations presented here, the biomass burning emissions were injected into the lowest layer only. Another reason for the large ozone values in the tropics and low values in the northern hemisphere may be due to a weak Brewer-Dobson circulation in the model. The top of the model is at $10 \mathrm{hPa}$, which may not be high enough to produce realistic circulation.

The comparison with surface observations highlights the advantage of an on-line model. The meteorological and transport signatures of ozone are well captured, but the climatological emissions used for this simulation do not capture any specific emission event which deviates from the general background values. In addition, our emissions are released into a $1.5^{\circ} \times 1.5^{\circ}$ grid square which for industrialized regions dilutes the $\mathrm{NO}_{\mathrm{x}}$ emissions and makes for more efficient ozone generation, as in much of the domain the gener- ation of ozone is $\mathrm{NO}_{\mathrm{x}}$-limited (Liu et al., 1987).

The comparison of model $\mathrm{NO}_{2}$ results and SCIAMACHY measurement data show that the overall patterns agree, the satellite data see more transport and higher values in background regions and the satellite data see larger column in polluted areas, in particular over China. Overall, the comparison of carbon monoxide and nitrogen dioxide output with MOPITT and SCIAMACHY measurements emphasizes the need for more accurate, year-specific emissions rates for biomass burning and anthropogenic sources.

In the development of the model we have tried to be as internally consistent as possible when using transport information for the tracers: for example, for boundary layer transport we use the mixing coefficients from the physics module. However, for large scale convective transport we are using the Kuo scheme for the dynamics while using ZhangMcFarlane for the tracers. We have commenced a study where we will use a Kain-Fritsch scheme modified for large scales for the dynamics, transport and lightning generation. At the same time we will implement in-cloud removal of gas species to reduce the overestimation of tropospheric $\mathrm{HNO}_{3}$. Also, in order to address the issue of the upper boundary conditions, we are extending the model to $0.1 \mathrm{hPa}$ and including stratospheric chemistry.

\section{Appendix A}

\section{Summary of gas-phase chemistry in GEM-AQ}

\footnotetext{
${ }^{1}$ Lupu, A., Kaminski, J. W., Neary, L., McConnell, J. C., Jarosz, J., Rinsland, C., Bernath, P., Walker, K. A., Boone, C., O’Neill, N. T., Hyer, E. J., and Reid, J. S.: Alaskan and western Canadian wildfires in the summer of 2004: GEM-AQ simulations and comparison with ACE satellite measurements, Atmos. Chem. Phys. Discuss., to be submitted, 2008.
} 
Table A1. List of gas-phase species.

\begin{tabular}{|c|c|c|c|c|c|c|}
\hline No. & Species & & Advected & Emitted & Dry-deposited & Wet-deposited \\
\hline 1 & $\mathrm{NO}_{2}$ & Nitrogen dioxide & $\mathrm{x}$ & $\mathrm{x}$ & $\mathrm{x}$ & \\
\hline 2 & $\mathrm{NO}$ & Nitric oxide & $\mathrm{x}$ & $\mathrm{x}$ & $\mathrm{x}$ & \\
\hline 3 & HONO & Nitrous oxide & $\mathrm{x}$ & & $\mathrm{x}$ & \\
\hline 4 & $\mathrm{NO}_{3}$ & Nitrate radical & & & & \\
\hline 5 & $\mathrm{~N}_{2} \mathrm{O}_{5}$ & Dinitrogen pentoxide & $\mathrm{x}$ & & & \\
\hline 6 & $\mathrm{HNO}_{4}$ & Pernitric acid & $\mathrm{x}$ & & & \\
\hline 7 & $\mathrm{HNO}_{3}$ & Nitric acid & $\mathrm{x}$ & & $\mathrm{x}$ & $\mathrm{x}$ \\
\hline 8 & $\mathrm{O}_{3}$ & Ozone & $\mathrm{x}$ & & $\mathrm{x}$ & \\
\hline 9 & $\mathrm{H}_{2} \mathrm{O}_{2}$ & Hydrogen peroxide & $\mathrm{x}$ & & $\mathrm{x}$ & $\mathrm{x}$ \\
\hline 10 & $\mathrm{SO}_{2}$ & Sulphur dioxide & $\mathrm{x}$ & $\mathrm{x}$ & $\mathrm{x}$ & $\mathrm{x}$ \\
\hline 11 & $\mathrm{SO}_{4}$ & Sulphate & $\mathrm{x}$ & $\mathrm{x}$ & $\mathrm{x}$ & $\mathrm{x}$ \\
\hline 12 & $\mathrm{O}$ & Ground-state oxygen atom & & & & \\
\hline 13 & $\mathrm{O}\left({ }^{1} \mathrm{D}\right)$ & Exited-state oxygen atom & & & & \\
\hline 14 & $\mathrm{OH}$ & Hydroxy radical & & & & \\
\hline 15 & $\mathrm{HO}_{2}$ & Hydroperoxy radical & & & $\mathrm{x}$ & \\
\hline 16 & $\mathrm{CO}$ & Carbon monoxide & $\mathrm{x}$ & $\mathrm{x}$ & & \\
\hline 17 & $\mathrm{CH}_{4}$ & Methane & & & & \\
\hline 18 & $\mathrm{C}_{2} \mathrm{H}_{6}$ & Ethane & $\mathrm{x}$ & $\mathrm{x}$ & & \\
\hline 19 & $\mathrm{C}_{3} \mathrm{H}_{8}$ & Propane and benzene & $\mathrm{x}$ & $\mathrm{x}$ & & \\
\hline 20 & ALKA & Higher alkanes & $\mathrm{x}$ & $\mathrm{x}$ & & \\
\hline 21 & ETHE & Ethene & $\mathrm{x}$ & $\mathrm{x}$ & & \\
\hline 22 & ALKE & Higher alkenes & $\mathrm{x}$ & $\mathrm{x}$ & & \\
\hline 23 & ISOP & Isoprene & $\mathrm{x}$ & $\mathrm{x}$ & & \\
\hline 24 & TOLU & Toluene \& other mono-substituted aromatics & $\mathrm{x}$ & $\mathrm{x}$ & & \\
\hline 25 & CRES & o-Cresol & $\mathrm{x}$ & & $\mathrm{x}$ & \\
\hline 26 & AROM & $\begin{array}{l}\text { Xylene and other di- \& tri-substituted } \\
\text { aromatics }\end{array}$ & $\mathrm{x}$ & $\mathrm{x}$ & & \\
\hline 27 & $\mathrm{C}_{2} \mathrm{H}_{2}$ & Acetylene & $\mathrm{x}$ & & & \\
\hline 28 & $\mathrm{HCHO}$ & Formaldehyde & $\mathrm{x}$ & $\mathrm{x}$ & $\mathrm{x}$ & $\mathrm{x}$ \\
\hline 29 & ALD2 & Acetaldehyde and higher aldehydes & $\mathrm{x}$ & $\mathrm{x}$ & $\mathrm{x}$ & \\
\hline 30 & MEK & Acetone and higher ketones & $\mathrm{x}$ & $\mathrm{x}$ & $\mathrm{x}$ & \\
\hline 31 & MGLY & Glyoxal and methyl glyoxal & $\mathrm{x}$ & & $\mathrm{x}$ & \\
\hline 32 & DIAL & Unsaturated di-carbonyls & $\mathrm{x}$ & & $\mathrm{x}$ & \\
\hline 33 & PAN & Peroxyacetyl nitrate and higher PANs & $\mathrm{x}$ & & $\mathrm{x}$ & \\
\hline 34 & $\mathrm{RNO}_{3}$ & Organic nitrate & $\mathrm{x}$ & & $\mathrm{x}$ & \\
\hline 35 & $\mathrm{ROOH}$ & Organic peroxide & $\mathrm{x}$ & & $\mathrm{x}$ & \\
\hline 36 & $\mathrm{MOOH}$ & Methyl hydroperoxide & $\mathrm{x}$ & & $\mathrm{x}$ & \\
\hline 37 & $\mathrm{MOH}$ & Methanol & $\mathrm{x}$ & & $\mathrm{x}$ & $\mathrm{x}$ \\
\hline 38 & PAA & Peroxyacetic acid & $\mathrm{x}$ & & $\mathrm{x}$ & $\mathrm{x}$ \\
\hline 39 & FRMA & Formic acid & $\mathrm{x}$ & & $\mathrm{x}$ & $\mathrm{x}$ \\
\hline 40 & ACTA & Acetic acid & $\mathrm{x}$ & & $\mathrm{x}$ & $\mathrm{x}$ \\
\hline 41 & $\mathrm{RO}_{2}$ & $\begin{array}{l}\text { Total } \mathrm{RO}_{2} \text { radicals } \\
\left(=\mathrm{RO}_{2} \mathrm{R}+\mathrm{R}_{2} \mathrm{O}_{2}+\mathrm{RO}_{2} \mathrm{~N}\right)\end{array}$ & & & $\mathrm{x}$ & \\
\hline 42 & $\mathrm{RO}_{2} \mathrm{R}$ & General organic peroxy radical \#1 & & & $\mathrm{x}$ & \\
\hline 43 & $\mathrm{R}_{2} \mathrm{O}_{2}$ & General organic peroxy radical \#2 & & & $\mathrm{x}$ & \\
\hline 44 & $\mathrm{RO}_{2} \mathrm{~N}$ & Alkyl nitrate forming organic peroxy radical & & & $\mathrm{x}$ & \\
\hline 45 & $\mathrm{MCO}_{3}$ & Acetyl peroxy radical & & & $\mathrm{x}$ & \\
\hline 46 & $\mathrm{MO}_{2}$ & Methylperoxy radical & & & $\mathrm{x}$ & \\
\hline 47 & $\mathrm{BZO}$ & Phenoxy radical & & & & \\
\hline 48 & CRG1 & Criegee radical \#1 & & & & \\
\hline 49 & CRG2 & Criegee radical \#2 & & & & \\
\hline 50 & $\mathrm{H}_{2} \mathrm{O}$ & Water vapour & $\mathrm{x}$ & & & \\
\hline
\end{tabular}


Table A2. List of gas-phase reactions excluding those of sulphur chemistry in CAM.

\begin{tabular}{|c|c|c|c|}
\hline No. & Reaction & Rate constant & Ref. \\
\hline G001 & $\mathrm{O}+\mathrm{O}_{2}+\mathrm{M} \rightarrow \mathrm{O}_{3}+\mathrm{M}$ & $k_{0}=1.57 \times 10^{-27} T^{-2.6}$ & 1. \\
\hline G002 & $\mathrm{O}+\mathrm{NO}_{2} \rightarrow \mathrm{NO}$ & $k=5.5 \times 10^{-12} \exp (188 / T)$ & 1. \\
\hline G003 & $\mathrm{O}+\mathrm{NO}_{2}+\mathrm{M} \rightarrow \mathrm{NO}_{3}+\mathrm{M}$ & $\begin{array}{l}k_{0}=6.75 \times 10^{-28} T^{-1.5} \\
k_{\infty}=5.85 \times 10^{-12} T^{0.24} \\
F_{c}=0.6\end{array}$ & 1. \\
\hline G004 & $\mathrm{NO}+\mathrm{O}_{3} \rightarrow \mathrm{NO}_{2}$ & $k=1.4 \times 10^{-12} \exp (-1310 / T)$ & 1. \\
\hline G005 & $\mathrm{NO}_{2}+\mathrm{O}_{3} \rightarrow \mathrm{NO}_{3}$ & $k=1.4 \times 10^{-13} \exp (-2470 / T)$ & 1. \\
\hline G006 & $\mathrm{NO}+\mathrm{NO}_{3} \rightarrow \mathrm{NO}_{2}+\mathrm{NO}_{2}$ & $k=1.8 \times 10^{-11} \exp (110 / T)$ & 1. \\
\hline G007 & $\mathrm{NO}+\mathrm{NO}\left(+\mathrm{O}_{2}\right) \rightarrow \mathrm{NO}_{2}+\mathrm{NO}_{2}$ & $k=3.3 \times 10^{-39} \exp (530 / T) \times[\mathrm{M}] \times 0.21$ & 1. \\
\hline G008 & $\mathrm{NO}_{2}+\mathrm{NO}_{3}+\mathrm{M} \rightarrow \mathrm{N}_{2} \mathrm{O}_{5}+\mathrm{M}$ & $\begin{array}{l}k_{0}=1.59 \times 10^{-19} T^{-4.4} \\
k_{\infty}=7.59 \times 10^{-11} T^{-0.7} \\
F_{C}=0.6\end{array}$ & 2. \\
\hline G009 & $\mathrm{N}_{2} \mathrm{O}_{5}+\mathrm{M} \rightarrow \mathrm{NO}_{2}+\mathrm{NO}_{3}+\mathrm{M}$ & $k_{\text {uni }}=3.7 \times 10^{26} \exp (-11000 / T) \times k_{\mathrm{G} 008}$ & 2. \\
\hline G010 & $\mathrm{N}_{2} \mathrm{O}_{5}+\mathrm{H}_{2} \mathrm{O} \rightarrow 2 \mathrm{HNO}_{3}$ & $k=2.5 \times 10^{-22}+1.8 \times 10^{-39} \times\left[\mathrm{H}_{2} \mathrm{O}\right]$ & 1. \\
\hline G011 & $\mathrm{NO}_{2}+\mathrm{NO}_{3} \rightarrow \mathrm{NO}+\mathrm{NO}_{2}$ & $k=4.5 \times 10^{-14} \exp (-1260 / T)$ & 2. \\
\hline G012 & $\mathrm{O}\left({ }^{1} \mathrm{D}\right)+\mathrm{H}_{2} \mathrm{O} \rightarrow 2 \mathrm{OH}$ & $k=2.2 \times 10^{-10}$ & 1. \\
\hline G013 & $\mathrm{O}\left({ }^{1} \mathrm{D}\right)+\mathrm{M} \rightarrow \mathrm{O}+\mathrm{M}$ & $\begin{aligned} k=0.78 & \times 1.8 \times 10^{-11} \exp (107 / T) \\
& +0.21 \times 3.2 \times 10^{-11} \exp (67 / T)\end{aligned}$ & 1. \\
\hline G014 & $\mathrm{NO}+\mathrm{OH}+\mathrm{M} \rightarrow \mathrm{HONO}+\mathrm{M}$ & $\begin{array}{l}k_{0}=6.52 \times 10^{-25} T^{-2.4} \\
k_{\infty}=1.83 \times 10^{-10} T^{-0.3} \\
F_{C}=0.81\end{array}$ & 1. \\
\hline G015 & $\mathrm{NO}_{2}+\mathrm{NO}_{2}+\mathrm{H}_{2} \mathrm{O} \rightarrow \mathrm{HNO}_{3}+\mathrm{HONO}$ & $k=1.0 \times 10^{-24}$ & 3 \\
\hline G016 & $\mathrm{NO}_{2}+\mathrm{OH}+\mathrm{M} \rightarrow \mathrm{HNO}_{3}+\mathrm{M}$ & $\begin{array}{l}k_{0}=8.91 \times 10^{-23} T^{-3.0} \\
k_{\infty}=4.1 \times 10^{-11} \\
F_{c}=0.4\end{array}$ & 1. \\
\hline G017 & $\mathrm{HNO}_{3}+\mathrm{OH} \rightarrow \mathrm{NO}_{3}$ & $\begin{array}{l}k=k_{1}+k_{2}[\mathrm{M}] /\left(1+k_{2}[\mathrm{M}] / k_{3}\right) \\
k_{1}=2.4 \times 10^{-14} \exp (460 / T) \\
k_{2}=6.5 \times 10^{-34} \exp (1335 / T) \\
k_{3}=2.7 \times 10^{-17} \exp (2199 / T)\end{array}$ & 1. \\
\hline G018 & $\mathrm{CO}+\mathrm{OH} \rightarrow \mathrm{HO}_{2}$ & $k=1.44 \times 10^{-13} \times\left(1+[\mathrm{M}] /\left(4.2 \times 10^{19}\right)\right)$ & 4. \\
\hline G019 & $\mathrm{OH}+\mathrm{O}_{3} \rightarrow \mathrm{HO}_{2}$ & $k=1.7 \times 10^{-12} \exp (-940 / T)$ & 1. \\
\hline G020 & $\mathrm{NO}+\mathrm{HO}_{2} \rightarrow \mathrm{NO}_{2}+\mathrm{OH}$ & $k=3.6 \times 10^{-12} \exp (270 / T)$ & 1. \\
\hline G021 & $\mathrm{HO}_{2}+\mathrm{NO}_{2}+\mathrm{M} \rightarrow \mathrm{HNO}_{4}+\mathrm{M}$ & $\begin{array}{l}k_{0}=5.29 \times 10^{-23} T^{-3.4} \\
k_{\infty}=1.54 \times 10^{-9} T^{-1.1} \\
F_{c}=0.6\end{array}$ & 2. \\
\hline G022 & $\mathrm{HNO}_{4}+\mathrm{M} \rightarrow \mathrm{NO}_{2}+\mathrm{HO}_{2}+\mathrm{M}$ & $k_{\text {uni }}=4.76 \times 10^{26} \exp (-10900 / T) \times k_{\mathrm{G} 021}$ & 2. \\
\hline G023 & $\mathrm{HNO}_{4}+\mathrm{OH} \rightarrow \mathrm{NO}_{2}$ & $k=3.2 \times 10^{-13} \exp (690 / T)$ & 5. \\
\hline G024 & $\mathrm{HO}_{2}+\mathrm{O}_{3} \rightarrow \mathrm{OH}$ & $k=9.71 \times 10^{-28} T^{4.57} \exp (693 / T)$ & 1. \\
\hline G025 & $\mathrm{HO}_{2}+\mathrm{HO}_{2} \rightarrow \mathrm{H}_{2} \mathrm{O}_{2}$ & $k=2.2 \times 10^{-13} \exp (600 / T)$ & 1. \\
\hline G026 & $\mathrm{HO}_{2}+\mathrm{HO}_{2}+\mathrm{M} \rightarrow \mathrm{H}_{2} \mathrm{O}_{2}+\mathrm{M}$ & $k_{0}=1.9 \times 10^{-33} \exp (980 / T)$ & 1. \\
\hline G027 & $\mathrm{HO}_{2}+\mathrm{HO}_{2} \rightarrow \mathrm{H}_{2} \mathrm{O}_{2}$ & $k=3.08 \times 10^{-34} \exp (2800 / T)\left[\mathrm{H}_{2} \mathrm{O}\right]$ & 1. \\
\hline G028 & $\mathrm{HO}_{2}+\mathrm{HO}_{2}+\mathrm{M} \rightarrow \mathrm{H}_{2} \mathrm{O}_{2}+\mathrm{M}$ & $k_{0}=2.66 \times 10^{-54} \exp (3180 / T)\left[\mathrm{H}_{2} \mathrm{O}\right]$ & 1. \\
\hline G029 & $\mathrm{H}_{2} \mathrm{O}_{2}+\mathrm{OH} \rightarrow \mathrm{HO}_{2}$ & $k=2.9 \times 10^{-12} \exp (-160 / T)$ & 1. \\
\hline G030 & $\mathrm{HO}_{2}+\mathrm{NO}_{3} \rightarrow \mathrm{OH}+\mathrm{NO}_{2}$ & $k=4.0 \times 10^{-12}$ & 1. \\
\hline G031 & $\mathrm{SO}_{2}+\mathrm{OH}+\mathrm{M} \rightarrow \mathrm{SO}_{4}+\mathrm{HO}_{2}+\mathrm{M}$ & $k=0.0$ (Handled in aerosol module) & \\
\hline G032 & $\mathrm{RO}_{2}+\mathrm{NO} \rightarrow \mathrm{NO}$ & $k=4.2 \times 10^{-12} \exp (180 / T)$ & 3. \\
\hline G033 & $\mathrm{RO}_{2}+\mathrm{HO}_{2} \rightarrow \mathrm{HO}_{2}$ & $k=1.75 \times 10^{-13} \exp (1000 / T)$ & 3. \\
\hline G034 & $\mathrm{RO}_{2}+\mathrm{RO}_{2} \rightarrow$ & $k=1.0 \times 10^{-15}$ & 3. \\
\hline G035 & $\mathrm{RO}_{2}+\mathrm{MCO}_{3} \rightarrow \mathrm{MCO}_{3}$ & $k=3.0 \times 10^{-12}$ & 3. \\
\hline G036 & $\mathrm{HCHO}+\mathrm{OH} \rightarrow \mathrm{CO}+\mathrm{HO}_{2}$ & $k=5.4 \times 10^{-12} \exp (135 / T)$ & 4. \\
\hline G037 & $\mathrm{HCHO}+\mathrm{NO}_{3} \rightarrow \mathrm{HNO}_{3}+\mathrm{CO}+\mathrm{HO}_{2}$ & $k=5.6 \times 10^{-16}$ & 4. \\
\hline G038 & $\mathrm{HCHO}+\mathrm{HO}_{2} \rightarrow \mathrm{RO}_{2}+\mathrm{RO}_{2} \mathrm{R}$ & $\begin{array}{l}k=k_{1} \times(1-1 / A) \\
k_{1}=1.1 \times 10^{-13} \\
A=1+2.1 \times 10^{-19} \exp (180 / T) \chi_{\mathrm{NO}}(\mathrm{ppmv})[\mathrm{M}]\end{array}$ & 3. \\
\hline
\end{tabular}


Table A2. Continued.

\begin{tabular}{|c|c|c|c|}
\hline No. & Reaction & Rate constant & Ref. \\
\hline G039 & $\mathrm{ALD} 2+\mathrm{OH} \rightarrow \mathrm{MCO}_{3}$ & $k=4.4 \times 10^{-12} \exp (365 / T)$ & 4. \\
\hline G040 & $\mathrm{ALD} 2+\mathrm{NO}_{3} \rightarrow \mathrm{HNO}_{3}+\mathrm{MCO}_{3}$ & $k=1.4 \times 10^{-12} \exp (-1860 / T)$ & 4. \\
\hline G041 & $\mathrm{MCO}_{3}+\mathrm{NO} \rightarrow \mathrm{MO}_{2}+\mathrm{NO}_{2}$ & $k=7.5 \times 10^{-12} \exp (290 / T)$ & 4. \\
\hline G042 & $\mathrm{MCO}_{3}+\mathrm{NO}_{2}+\mathrm{M} \rightarrow \mathrm{PAN}+\mathrm{M}$ & $\begin{array}{l}k_{0}=7.22 \times 10^{-15} T^{-5.6} \\
k_{\infty}=4.83 \times 10^{-8} T^{-1.5} \\
F_{c}=0.6\end{array}$ & 2. \\
\hline G043 & $\mathrm{MCO}_{3}+\mathrm{HO}_{2} \rightarrow \alpha_{1} \mathrm{PAA}+\alpha_{2} \mathrm{ACTA}+\alpha_{2} \mathrm{O}_{3}$ & $\begin{array}{l}k=5.2 \times 10^{-13} \exp (980 / T) \\
\alpha_{1}=1-\alpha_{2} \\
\alpha_{2}=\min \left(1.0,8.5 \times 10^{-3} \exp (1020 / T)\right)\end{array}$ & 7., 8 . \\
\hline G044 & $\mathrm{MCO}_{3}+\mathrm{MCO}_{3} \rightarrow 2 \mathrm{MO}_{2}$ & $k=2.9 \times 10^{-12} \exp (500 / T)$ & 4. \\
\hline G045 & $\mathrm{PAN}+\mathrm{M} \rightarrow \mathrm{NO}_{2}+\mathrm{MCO}_{3}+\mathrm{M}$ & $k_{\mathrm{uni}}=1.11 \times 10^{28} \exp (-14000 / T) \times k_{\mathrm{G} 042}$ & 2. \\
\hline G046 & $\begin{aligned} \mathrm{MEK}+\mathrm{OH} \rightarrow & 0.5 \mathrm{HCHO}+0.5 \mathrm{ALD} 2+1.5 \mathrm{RO}_{2} \\
& +1.5 \mathrm{RO}_{2} \mathrm{R}+\mathrm{MCO}_{3}\end{aligned}$ & $k=1.2 \times 10^{-11} \exp (-745 / T)$ & 3. \\
\hline G047 & $\mathrm{MGLY}+\mathrm{OH} \rightarrow \mathrm{CO}+\mathrm{MCO}_{3}$ & $k=1.5 \times 10^{-11}$ & 4. \\
\hline G048 & $\mathrm{MGLY}+\mathrm{NO}_{3} \rightarrow \mathrm{HNO}_{3}+\mathrm{CO}+\mathrm{MCO}_{3}$ & $k=3.0 \times 10^{-13} \exp (-1427 / T)$ & 3. \\
\hline G049 & $\mathrm{CH}_{4}+\mathrm{OH} \rightarrow \mathrm{MO}_{2}$ & $k=2.8 \times 10^{-14} T^{0.667} \exp (-1575 / T)$ & 2. \\
\hline G050 & $\mathrm{C}_{2} \mathrm{H}_{6}+\mathrm{OH} \rightarrow \mathrm{ALD} 2+\mathrm{RO}_{2}+\mathrm{RO}_{2} \mathrm{R}$ & $k=6.9 \times 10^{-12} \exp (-1000 / T)$ & 4. \\
\hline G051 & $\mathrm{C}_{3} \mathrm{H}_{8}+\mathrm{OH} \rightarrow 0.3 \mathrm{ALD} 2+0.5 \mathrm{MEK}+\mathrm{RO}_{2}+\mathrm{RO}_{2} \mathrm{R}$ & $k=1.65 \times 10^{-17} T^{2} \exp (-87 / T)$ & 4. \\
\hline G052 & $\begin{aligned} \mathrm{ALKA}+\mathrm{OH} \rightarrow & \beta_{\mathrm{pt}(1)} \mathrm{HCHO}+\beta_{\mathrm{pt}(2)} \mathrm{ALD} 2 \\
& +\beta_{\mathrm{pt}(3)} \mathrm{MEK}+\beta_{\mathrm{pt}(4)} \mathrm{RO}_{2} \mathrm{~N} \\
& +\beta_{\mathrm{pt}(5)} \mathrm{RO}_{2} \mathrm{R}+\beta_{\mathrm{pt}(6)} \mathrm{R}_{2} \mathrm{O}_{2}+\beta_{\mathrm{pt}(7)} \mathrm{RO}_{2}\end{aligned}$ & $\begin{array}{l}k=X k_{1}+(1-X) k_{2} \\
k_{1}=1.017 \times 10^{-11} \exp (-354 / T) \\
k_{2}=2.312 \times 10^{-11} \exp (-289 / T)\end{array}$ & 3.,a. \\
\hline G053 & $\begin{aligned} \mathrm{RNO}_{3}+\mathrm{OH} \rightarrow & 0.16 \mathrm{HCHO}+1.53 \mathrm{ALD} 2+0.15 \mathrm{MEK} \\
& +\mathrm{NO}_{2}+1.39 \mathrm{RO}_{2}+1.39 \mathrm{R}_{2} \mathrm{O}_{2}\end{aligned}$ & $k=2.19 \times 10^{-11} \exp (-709 / T)$ & 3. \\
\hline G054 & $\mathrm{RO}_{2} \mathrm{~N}+\mathrm{NO} \rightarrow \mathrm{RNO}_{3}$ & $k=4.2 \times 10^{-12} \exp (180 / T)$ & 3. \\
\hline G055 & $\mathrm{RO}_{2} \mathrm{~N}+\mathrm{HO}_{2} \rightarrow \mathrm{MEK}+\mathrm{ROOH}$ & $k=1.75 \times 10^{-13} \exp (1000 / T)$ & 3. \\
\hline G056 & $\mathrm{RO}_{2} \mathrm{~N}+\mathrm{RO}_{2} \rightarrow \mathrm{MEK}+0.5 \mathrm{HO}_{2}+\mathrm{RO}_{2}$ & $k=1.0 \times 10^{-15}$ & 3. \\
\hline G057 & $\mathrm{RO}_{2} \mathrm{~N}+\mathrm{MCO}_{3} \rightarrow 0.7 \mathrm{MO}_{2}+0.7 \mathrm{HO}_{2}+0.3 \mathrm{ACTA}+\mathrm{MEK}$ & $k=3.0 \times 10^{-12}$ & 3., 9 . \\
\hline G058 & $\mathrm{R}_{2} \mathrm{O}_{2}+\mathrm{NO} \rightarrow \mathrm{NO}_{2}$ & $k=4.2 \times 10^{-12} \exp (180 / T)$ & 3. \\
\hline G059 & $\mathrm{R}_{2} \mathrm{O}_{2}+\mathrm{HO}_{2} \rightarrow \mathrm{ROOH}$ & $k=1.75 \times 10^{-13} \exp (1000 / T)$ & 3. \\
\hline G060 & $\mathrm{R}_{2} \mathrm{O}_{2}+\mathrm{RO}_{2} \rightarrow \mathrm{RO}_{2}$ & $k=1.0 \times 10^{-15}$ & 3 \\
\hline G061 & $\mathrm{R}_{2} \mathrm{O}_{2}+\mathrm{MCO}_{3} \rightarrow 0.7 \mathrm{MO}_{2}+0.3$ ACTA & $k=3.0 \times 10^{-12}$ & 3., 9 . \\
\hline G062 & $\mathrm{RO}_{2} \mathrm{R}+\mathrm{NO} \rightarrow \mathrm{NO}_{2}+\mathrm{HO}_{2}$ & $k=4.2 \times 10^{-12} \exp (180 / T)$ & 3. \\
\hline G063 & $\mathrm{RO}_{2} \mathrm{R}+\mathrm{HO}_{2} \rightarrow \mathrm{ROOH}$ & $k=1.75 \times 10^{-13} \exp (1000 / T)$ & 3. \\
\hline G064 & $\mathrm{RO}_{2} \mathrm{R}+\mathrm{RO}_{2} \rightarrow 0.5 \mathrm{HO}_{2}+\mathrm{RO}_{2}$ & $k=1.0 \times 10^{-15}$ & 3. \\
\hline G065 & $\mathrm{RO}_{2} \mathrm{R}+\mathrm{MCO}_{3} \rightarrow 0.7 \mathrm{MO}_{2}+0.7 \mathrm{HO}_{2}+0.3 \mathrm{ACTA}$ & $k=3.0 \times 10^{-12}$ & 3., 9 . \\
\hline G066 & $\mathrm{ETHE}+\mathrm{OH} \rightarrow 1.56 \mathrm{HCHO}+0.22 \mathrm{ALD} 2+\mathrm{RO}_{2}+\mathrm{RO}_{2} \mathrm{R}$ & $\begin{array}{l}k_{0}=4.11 \times 10^{-21} T^{-3.1} \\
k_{\infty}=1.15 \times 10^{-9} T^{-0.85} \\
F_{c}=0.48\end{array}$ & 10. \\
\hline G067 & $\mathrm{ETHE}+\mathrm{O}_{3} \rightarrow \mathrm{HCHO}+0.42 \mathrm{CO}+0.4 \mathrm{CRG} 1+0.12 \mathrm{HO}_{2}$ & $k=9.1 \times 10^{-15} \exp (-2580 / T)$ & 4. \\
\hline G068 & $\mathrm{ETHE}+\mathrm{O} \rightarrow \mathrm{HCHO}+\mathrm{CO}+\mathrm{HO}_{2}+\mathrm{RO}_{2}+\mathrm{RO}_{2} \mathrm{R}$ & $k=1.04 \times 10^{-11} \exp (-792 / T)$ & 3. \\
\hline G069 & $\mathrm{ETHE}+\mathrm{NO}_{3} \rightarrow 2 \mathrm{HCHO}+\mathrm{NO}_{2}+\mathrm{RO}_{2}+\mathrm{R}_{2} \mathrm{O}_{2}$ & $k=3.3 \times 10^{-12} \exp (-2880 / T)$ & 4. \\
\hline G070 & $\mathrm{ALKE}+\mathrm{OH} \rightarrow \beta_{\mathrm{c}(1)} \mathrm{HCHO}+\beta_{\mathrm{c}(2)} \mathrm{ALD} 2+\mathrm{RO}_{2}+\mathrm{RO}_{2} \mathrm{R}$ & $\begin{array}{l}k=Y k_{1}+(1-Y) k_{2} \\
k_{1}=5.323 \times 10^{-12} \exp (504 / T) \\
k_{2}=1.074 \times 10^{-11} \exp (549 / T)\end{array}$ & 3.,b. \\
\hline G071 & $\begin{aligned} \mathrm{ALKE}+\mathrm{O}_{3} \rightarrow & \beta_{\mathrm{c}(3)} \mathrm{HCHO}+\beta_{\mathrm{c}(4)} \mathrm{ALD} 2+\beta_{\mathrm{c}(5)} \mathrm{RO}_{2} \\
& +\beta_{\mathrm{c}(5)} \mathrm{RO}_{2} \mathrm{R}+\beta_{\mathrm{c}(6)} \mathrm{HO}_{2}+\beta_{\mathrm{c}(7)} \mathrm{OH} \\
& +\beta_{\mathrm{c}(8)} \mathrm{CO}+\beta_{\mathrm{c}(18)} \mathrm{CRG} 1+\beta_{\mathrm{c}(19)} \mathrm{CRG} 2\end{aligned}$ & $\begin{array}{l}k=Y k_{1}+(1-Y) k_{2} \\
k_{1}=1.323 \times 10^{-14} \exp (-2105 / T) \\
k_{2}=7.333 \times 10^{-15} \exp (-1137 / T)\end{array}$ & 3.,b. \\
\hline G072 & 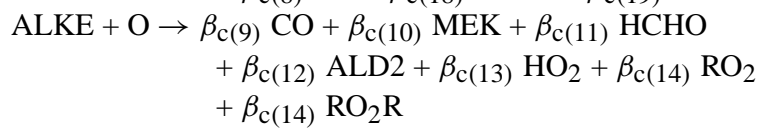 & $\begin{array}{l}k=Y k_{1}+(1-Y) k_{2} \\
k_{1}=1.18 \times 10^{-11} \exp (-324 / T) \\
k_{2}=2.26 \times 10^{-11} \exp (10 / T)\end{array}$ & 3.,b. \\
\hline G073 & $\begin{aligned} \mathrm{ALKE}+\mathrm{NO}_{3} \rightarrow & \beta_{\mathrm{c}(1)} \mathrm{HCHO}+\beta_{\mathrm{c}(2)} \mathrm{ALD} 2+\mathrm{NO}_{2}+\mathrm{RO}_{2} \\
& +\mathrm{R}_{2} \mathrm{O}_{2}\end{aligned}$ & $\begin{array}{l}k=Y k_{1}+(1-Y) k_{2} \\
k_{1}=1.143 \times 10^{-11} \exp (-1935 / T) \\
k_{2}=3.23 \times 10^{-11} \exp (-975 / T)\end{array}$ & 3.,b. \\
\hline
\end{tabular}


Table A2. Continued.

\begin{tabular}{|c|c|c|c|}
\hline No. & Reaction & Rate constant & Ref. \\
\hline G074 & $\mathrm{CRG} 1+\mathrm{H}_{2} \mathrm{O} \rightarrow$ FRMA & $k=2.3 \times 10^{-17}$ & 3. \\
\hline G075 & $\mathrm{CRG} 2+\mathrm{H}_{2} \mathrm{O} \rightarrow$ ACTA & $k=2.3 \times 10^{-17}$ & 3. \\
\hline G076 & $\mathrm{HCHO}+\mathrm{CRG} 1 \rightarrow$ & $k=2.5 \times 10^{-14}$ & 3. \\
\hline G077 & $\mathrm{HCHO}+\mathrm{CRG} 2 \rightarrow$ & $k=2.5 \times 10^{-14}$ & 3. \\
\hline G078 & $\mathrm{ALD} 2+\mathrm{CRG} 1 \rightarrow$ & $k=2.5 \times 10^{-14}$ & 3. \\
\hline G079 & $\mathrm{ALD} 2+\mathrm{CRG} 2 \rightarrow$ & $k=2.5 \times 10^{-14}$ & 3. \\
\hline G080 & $\begin{aligned} \mathrm{TOLU}+\mathrm{OH} \rightarrow & 0.11 \mathrm{HCHO}+0.14 \mathrm{MGLY}+0.4 \mathrm{DIAL} \\
& +0.11 \mathrm{CO}+0.16 \mathrm{CRES}+0.16 \mathrm{HO}_{2} \\
& +0.84 \mathrm{RO}_{2}+0.84 \mathrm{RO}_{2} \mathrm{R}\end{aligned}$ & $k=2.1 \times 10^{-12} \exp (322 / T)$ & 3. \\
\hline G081 & $\begin{aligned} \mathrm{AROM}+\mathrm{OH} \rightarrow & \beta_{\mathrm{c}(15)} \mathrm{DIAL}+\beta_{\mathrm{c}(16)} \mathrm{MGLY}+\beta_{\mathrm{c}(17)} \mathrm{HCHO} \\
& +\beta_{\mathrm{c}(17)} \mathrm{CO}+0.17 \mathrm{CRES}+0.17 \mathrm{HO}_{2} \\
& +0.83 \mathrm{RO}_{2}+0.83 \mathrm{RO}_{2} \mathrm{R}\end{aligned}$ & $\begin{array}{l}k=Z k_{1}+(1-Z) k_{2} \\
k_{1}=1.407 \times 10^{-11} \exp (116 / T) \\
k_{2}=4.77 \times 10^{-11}\end{array}$ & 3.,b. \\
\hline G082 & $\mathrm{DIAL}+\mathrm{OH} \rightarrow \mathrm{MCO}_{3}$ & $k=3.0 \times 10^{-11}$ & 3. \\
\hline G083 & $\begin{aligned} \mathrm{CRES}+\mathrm{OH} \rightarrow & 0.2 \mathrm{MGLY}+0.08 \mathrm{CRES}+\mathrm{RO}_{2}+0.85 \mathrm{RO}_{2} \mathrm{R} \\
& +0.15 \mathrm{RO}_{2} \mathrm{~N}\end{aligned}$ & $k=4.0 \times 10^{-11}$ & 3. \\
\hline G084 & $\mathrm{CRES}+\mathrm{NO}_{3} \rightarrow \mathrm{HNO}_{3}+\mathrm{BZO}+0.5 \mathrm{CRES}$ & $k=2.2 \times 10^{-11}$ & 3. \\
\hline G085 & $\mathrm{BZO}+\mathrm{NO}_{2} \rightarrow \mathrm{RNO}_{3}$ & $k=1.5 \times 10^{-11}$ & 3. \\
\hline G086 & $\mathrm{BZO}+\mathrm{HO}_{2} \rightarrow$ & $k=1.75 \times 10^{-13} \exp (1000 / T)$ & 3. \\
\hline G087 & $\mathrm{BZO} \rightarrow$ & $k_{\text {uni }}=1.0 \times 10^{-3}$ & 3. \\
\hline G088 & $\begin{aligned} \mathrm{ISOP}+\mathrm{OH} \rightarrow & \text { ETHE }+\mathrm{HCHO}+0.2 \mathrm{ALD} 2+0.27 \mathrm{MGLY} \\
& +0.7 \mathrm{HO}_{2}+\mathrm{RO}_{2}+0.9 \mathrm{R}_{2} \mathrm{O}_{2}+0.2 \mathrm{MCO}_{3} \\
& +0.1 \mathrm{RO}_{2} \mathrm{~N}\end{aligned}$ & $k=2.7 \times 10^{-11} \exp (390 / T)$ & 4. \\
\hline G089 & $\begin{array}{c}\mathrm{ISOP}+\mathrm{O}_{3} \rightarrow \\
0.5 \mathrm{ETHE}+\mathrm{HCHO}+0.4 \mathrm{ALD} 2+0.2 \mathrm{MGLY} \\
+0.2 \mathrm{CRG} 2+0.4 \mathrm{HO}_{2}+0.1 \mathrm{OH}\end{array}$ & $k=1.03 \times 10^{-14} \exp (-1995 / T)$ & 4. \\
\hline G090 & $\mathrm{ISOP}+\mathrm{O} \rightarrow \mathrm{ETHE}+\mathrm{ALD} 2+0.6 \mathrm{HO}_{2}+0.5 \mathrm{RO}_{2}+0.5 \mathrm{R}_{2} \mathrm{O}_{2}$ & $k=1.8 \times 10^{-11}$ & 3. \\
\hline G091 & $\mathrm{ISOP}+\mathrm{NO}_{3} \rightarrow \mathrm{HCHO}+\mathrm{ALD} 2+\mathrm{NO}_{2}+\mathrm{RO}_{2}+\mathrm{R}_{2} \mathrm{O}_{2}$ & $k=3.15 \times 10^{-12} \exp (-450 / T)$ & 4. \\
\hline G092 & $\mathrm{OH}+\mathrm{HO}_{2} \rightarrow$ & $k=4.8 \times 10^{-11} \exp (250 / T)$ & 1. \\
\hline G093 & $\mathrm{ROOH}+\mathrm{OH} \rightarrow 0.5 \mathrm{OH}+0.5 \mathrm{RO}_{2}+0.5 \mathrm{RO}_{2} \mathrm{R}$ & $k=4.0 \times 10^{-12} \exp (180 / T)$ & 3. \\
\hline G094 & $\mathrm{C}_{2} \mathrm{H}_{2}+\mathrm{OH}+\mathrm{M} \rightarrow$ & $\begin{array}{l}k_{0}=2.6 \times 10^{-26} T^{-1.5} \\
k_{\infty}=1.0 \times 10^{-12} \\
F_{c}=0.37\end{array}$ & 11. \\
\hline G095 & $\mathrm{RO}_{2} \mathrm{~N}+\mathrm{MO}_{2} \rightarrow 0.75 \mathrm{HCHO}+0.25 \mathrm{MOH}+\mathrm{HO}_{2}+\mathrm{MEK}$ & $k=1.0 \times 10^{-15}$ & $=k_{\mathrm{G} 056}$ \\
\hline G096 & $\mathrm{RO}_{2} \mathrm{~N}+\mathrm{NO}_{3} \rightarrow \mathrm{NO}_{2}+\mathrm{HO}_{2}+\mathrm{MEK}$ & $k=2.5 \times 10^{-12}$ & 9. \\
\hline G097 & $\mathrm{R}_{2} \mathrm{O}_{2}+\mathrm{MO}_{2} \rightarrow 0.5 \mathrm{HCHO}+0.5 \mathrm{MO}_{2}$ & $k=1.0 \times 10^{-15}$ & $=k_{\mathrm{G} 060}$ \\
\hline G098 & $\mathrm{R}_{2} \mathrm{O}_{2}+\mathrm{NO}_{3} \rightarrow \mathrm{NO}_{2}$ & $k=2.5 \times 10^{-12}$ & 9. \\
\hline G099 & $\mathrm{RO}_{2}+\mathrm{MO}_{2} \rightarrow \mathrm{MO}_{2}$ & $k=1.0 \times 10^{-15}$ & $=k_{\mathrm{G} 034}$ \\
\hline G100 & $\mathrm{RO}_{2}+\mathrm{NO}_{3} \rightarrow \mathrm{NO}_{3}$ & $k=2.5 \times 10^{-12}$ & 9. \\
\hline G101 & $\mathrm{RO}_{2} \mathrm{R}+\mathrm{MO}_{2} \rightarrow \mathrm{HO}_{2}+0.75 \mathrm{HCHO}+0.25 \mathrm{MO}_{2}$ & $k=1.0 \times 10^{-15}$ & $=k_{\mathrm{G} 064}$ \\
\hline G102 & $\mathrm{RO}_{2} \mathrm{R}+\mathrm{NO}_{3} \rightarrow \mathrm{NO}_{2}+\mathrm{HO}_{2}$ & $k=2.5 \times 10^{-12}$ & 9. \\
\hline G103 & $\mathrm{MCO}_{3}+\mathrm{NO}_{3} \rightarrow \mathrm{MO}_{2}+\mathrm{NO}_{2}$ & $k=4.1 \times 10^{-12}$ & 9. \\
\hline G104 & $\mathrm{PAN}+\mathrm{OH} \rightarrow \mathrm{HCHO}+\mathrm{CO}+\mathrm{NO}_{2}$ & $k=2.0 \times 10^{-14}$ & 4. \\
\hline G105 & $\mathrm{FRMA}+\mathrm{OH} \rightarrow \mathrm{HO}_{2}$ & $k=4.5 \times 10^{-13}$ & 4. \\
\hline G106 & $\mathrm{ACTA}+\mathrm{OH} \rightarrow \mathrm{MO}_{2}$ & $k=4.2 \times 10^{-14} \exp (855 / T)$ & 12. \\
\hline G107 & $\mathrm{MO}_{2}+\mathrm{NO} \rightarrow \mathrm{NO}_{2}+\mathrm{HCHO}+\mathrm{HO}_{2}$ & $k=2.3 \times 10^{-12} \exp (360 / T)$ & 13. \\
\hline G108 & $\mathrm{MO}_{2}+\mathrm{HO}_{2} \rightarrow \mathrm{MOOH}$ & $k=3.8 \times 10^{-13} \exp (780 / T)$ & 4. \\
\hline G109 & $\mathrm{MO}_{2}+\mathrm{MO}_{2} \rightarrow 2 \mathrm{HCHO}+2 \mathrm{HO}_{2}$ & $k=7.4 \times 10^{-13} \exp (-520 / T)$ & 4. \\
\hline G110 & $\mathrm{MO}_{2}+\mathrm{MO}_{2} \rightarrow \mathrm{HCHO}+\mathrm{MOH}$ & $k=1.03 \times 10^{-13} \exp (365 / T)-k_{\mathrm{G} 109}$ & 4. \\
\hline G111 & $\mathrm{MO}_{2}+\mathrm{MCO}_{3} \rightarrow \mathrm{HCHO}+\alpha_{3} \mathrm{HO}_{2}+\alpha_{3} \mathrm{MO}_{2}+\alpha_{4} \mathrm{ACTA}$ & $\begin{array}{l}k=2.0 \times 10^{-12} \exp (500 / T) \\
\alpha_{3}=1-\alpha_{4}\end{array}$ & 4. \\
\hline G112 & $\mathrm{MO}_{2}+\mathrm{NO}_{3} \rightarrow \mathrm{NO}_{2}+\mathrm{HCHO}+\mathrm{HO}_{2}$ & $\begin{array}{l}\alpha_{4}=\min \left(1.0,6.1 \times 10^{-6} \exp (2990 / T)\right) \\
k=1.3 \times 10^{-12}\end{array}$ & $\begin{array}{l}7 ., 8 . \\
4 .\end{array}$ \\
\hline
\end{tabular}


Table A2. Continued.

\begin{tabular}{|c|c|c|c|}
\hline No. & Reaction & Rate constant & Ref. \\
\hline G113 & $\mathrm{MOOH}+\mathrm{OH} \rightarrow 0.65 \mathrm{MO}_{2}+0.35 \mathrm{HCHO}+0.35 \mathrm{OH}$ & $k=2.9 \times 10^{-12} \exp (190 / T)$ & 4. \\
\hline G114 & $\mathrm{MOH}+\mathrm{OH} \rightarrow \mathrm{HCHO}+\mathrm{HO}_{2}$ & $k=2.85 \times 10^{-12} \exp (-345 / T)$ & 14. \\
\hline G115 & $\mathrm{PAA}+\mathrm{OH} \rightarrow \mathrm{MCO}_{3}$ & $k=3.7 \times 10^{-12}$ & 9. \\
\hline G116 & $\mathrm{N}_{2} \mathrm{O}_{5}+\mathrm{H}_{2} \mathrm{O} \rightarrow 2 \mathrm{HNO}_{3}$ & $\gamma= \begin{cases}0.001+0.068 \mathrm{RH} & (0 \leq \mathrm{RH}<0.5) \\
0.035 & (0.5 \leq \mathrm{RH} \leq 1)\end{cases}$ & 15. \\
\hline
\end{tabular}

References:

1. Atkinson et al. (2004);

2. Sander et al. (2006);

3. Stockwell and Lurmann (1989);

4. Atkinson et al. (2005);

5. IUPAC (2005a);

6. IUPAC (2005b);

7. Atkinson et al. (1999);

8. Horie and Moortgat (1992);

9. Saunders et al. (2003);

10. IUPAC (2005c);

11. IUPAC (2005d);

12. IUPAC (2005e);

13. IUPAC (2005f);

14. IUPAC $(2005 \mathrm{~g})$;

15. Thornton et al. (2003).

Notes:

a. The product coefficients $\beta_{p t(i)}(i=1-7)$ are allowed to change as a function of pressure and temperature where predefined tables for C4-C5 alkanes and >C6 alkanes are used to obtain the coefficients by linear interpolation in pressure and temperature as well as by weighting between the lumping mole fractions $X$ and $1-X$ (Stockwell and Lurmann, 1989);

b. The product coefficients $\beta_{c(i)}$ are assigned based on the assumed lumping mole fractions: $Y$ for $i=1-14$ and 18-19 and $Z$ for $i=15-17$ (Stockwell and Lurmann, 1989). 
Table A3. List of photolysis reactions.

\begin{tabular}{lll}
\hline No. & Reaction & Ref. \\
\hline $\mathrm{P} 01$ & $\mathrm{NO}_{2}+\mathrm{h} v \rightarrow \mathrm{NO}+\mathrm{O}$ & 1. \\
$\mathrm{P} 02$ & $\mathrm{NO}_{3}+\mathrm{h} v \rightarrow \mathrm{NO}$ & 1. \\
$\mathrm{P} 03$ & $\mathrm{NO}_{3}+\mathrm{h} v \rightarrow \mathrm{NO}_{2}+\mathrm{O}$ & 1. \\
$\mathrm{P} 04$ & $\mathrm{O}_{3}+\mathrm{h} v \rightarrow \mathrm{O}$ & $2 ., 3$. \\
$\mathrm{P} 05$ & $\mathrm{O}_{3}+\mathrm{h} v \rightarrow \mathrm{O}\left({ }^{1} \mathrm{D}\right)$ & $2 ., 3$. \\
$\mathrm{P} 06$ & $\mathrm{HONO}+\mathrm{h} v \rightarrow \mathrm{NO}+\mathrm{OH}$ & 1. \\
$\mathrm{P} 07$ & $\mathrm{HNO}_{3}+\mathrm{h} v \rightarrow \mathrm{NO}_{2}+\mathrm{OH}$ & 1. \\
$\mathrm{P} 08$ & $\mathrm{HNO}_{4}+\mathrm{h} v \rightarrow \mathrm{NO}_{2}+\mathrm{HO}_{2}$ & 1. \\
$\mathrm{P} 09$ & $\mathrm{H}_{2} \mathrm{O}_{2}+\mathrm{h} v \rightarrow 2 \mathrm{OH}$ & 1. \\
$\mathrm{P} 10$ & $\mathrm{ROOH}+\mathrm{h} v \rightarrow \mathrm{HO}_{2}+\mathrm{OH}$ & $=J_{\mathrm{P} 17}$ \\
$\mathrm{P} 11$ & $\mathrm{HCHO}+\mathrm{h} v \rightarrow \mathrm{CO}+2 \mathrm{HO}_{2}$ & 1. \\
$\mathrm{P} 12$ & $\mathrm{HCHO}+\mathrm{h} v \rightarrow \mathrm{CO}$ & 1. \\
$\mathrm{P} 13$ & $\mathrm{ALD} 2+\mathrm{h} v \rightarrow \mathrm{MO}_{2}+\mathrm{CO}_{2}+\mathrm{HO}_{2}$ & $4 ., 5$. \\
$\mathrm{P} 14$ & $\mathrm{MEK}+\mathrm{h} v \rightarrow \mathrm{ALD}_{2}+\mathrm{RO}_{2}+\mathrm{RO}_{2} \mathrm{R}+\mathrm{MCO}_{3}$ & 6. \\
$\mathrm{P} 15$ & $\mathrm{MGLY}+\mathrm{h} v \rightarrow \mathrm{CO}+\mathrm{HO}_{2}+\mathrm{MCO}_{3}$ & 7. \\
$\mathrm{P} 16$ & $\mathrm{DIAL}+\mathrm{h} v \rightarrow \mathrm{CO}+\mathrm{HO}_{2}+\mathrm{MCO}_{3}$ & $8 .,=J_{\mathrm{P} 01} \times 0.005$ \\
$\mathrm{P} 17$ & $\mathrm{MOOH}+\mathrm{h} v \rightarrow \mathrm{HCHO}^{2} \mathrm{HO}_{2}+\mathrm{OH}$ & 1. \\
$\mathrm{P} 18$ & $\mathrm{PAA}+\mathrm{h} v \rightarrow \mathrm{MO}_{2}+\mathrm{OH}$ & 9. \\
$\mathrm{P} 19$ & $\mathrm{PAN}+\mathrm{h} v \rightarrow \mathrm{MCO}_{3}+\mathrm{NO}_{2}$ & 1. \\
\hline
\end{tabular}

References for absorption cross sections and quantum yields:

1. DeMore et al. (1997);

2. Molina and Molina (1986);

3. Talukdar et al. (1998);

4. Calvert and Pitts (1966);

5. Atkinson and Lloyd (1984);

6. Crowley, J. N., unpublished data;

7. Plum et al. (1983);

8. Lurmann et al. (1986);

9. Giguère and Olmos (1956). 
Table A4. Emissions. All VOC emissions are given in $\mathrm{TgC} / \mathrm{year}, \mathrm{NO}$ and $\mathrm{NO}_{2}$ in $\mathrm{TgN} / \mathrm{year}, \mathrm{SO}_{2}$ in $\mathrm{TgS} / \mathrm{year}$, and $\mathrm{CO}$ in $\mathrm{TgCO} / \mathrm{year}$.

\begin{tabular}{llllll}
\hline Species & Industrial & Biogenic & $\begin{array}{l}\text { Fuelwood and agricultural } \\
\text { waste burning }\end{array}$ & $\begin{array}{l}\text { Forest and savannah } \\
\text { burning }\end{array}$ & Lightning \\
\hline C3H8 & 5.0 & 2.7 & 0.96 & 1.6 \\
TOLU & 4.1 & & & \\
AROM & 6.8 & 138.9 & 15.7 & 4.1 \\
ETHE & 2.0 & 12.6 & 4.8 & 9.2 \\
HCHO & 0.25 & & & \\
MEK & 0.7 & & & \\
ALD2 & 0.34 & & & 3.3 \\
ALKA & 38.4 & 111.1 & 12.5 & 470.4 \\
CO & 306.7 & 19.9 & 377.6 & 2.96 \\
C2H6 & 3.2 & 1.6 & 2.45 & 0.82 \\
ISOP & & 501.0 & & 6.5 \\
ALKE & & 27.3 & 3.1 & \\
NO & 21.9 & 6.6 & 3.5 & \\
NO2 & 1.15 & & & \\
SO2 & 71.6 & & & \\
\hline
\end{tabular}


Acknowledgements. The authors wish to thank S. Gravel and colleagues at MSC for their assistance and advice with GEM and R. Sander for providing the MESSy photolysis module. The authors wish to acknowledge financial support from the Canadian Foundation for Climate and Atmospheric Sciences, Environment Canada, the Natural Sciences and Engineering Research Council of Canada, the Canadian Foundation for Innovation and the Ontario Innovation Trust. Also, we thank A. Hussain and M. Niesh for technical assistance. The authors also thank the four anonymous reviewers for their very helpful comments.

Edited by: P. Haynes

\section{References}

Atkinson, R. and Lloyd, A. C.: Evaluation of kinetic and mechanistic data for modeling of photochemical smog, J. Phys. Chem. Ref. Data, 13, 315-444, 1984.

Atkinson, R., Baulch, D. L., Cox, R. A., Hampson, Jr., R. F., Kerr, J. A., Rossi, M. J., and Troe, J.: Evaluated kinetic and photochemical for atmospheric chemistry, Organic Species: Supplement VII, IUPAC Subcommittee on Gas Kinetic Data Evaluation for Atmospheric Chemistry, J. Phys. Chem. Ref. Data, 28, 191393, 1999.

Atkinson, R., Baulch, D. L., Cox, R. A., Crowley, J. N., Hampson, R. F., Hynes, R. G., Jenkin, M. E., Rossi, M. J., and Troe, J.: Evaluated kinetic and photochemical data for atmospheric chemistry: Volume I - gas phase reactions of $\mathrm{O}_{\mathrm{x}}, \mathrm{HO}_{\mathrm{x}}, \mathrm{NO}_{\mathrm{x}}$ and $\mathrm{SO}_{\mathrm{x}}$ species, Atmos. Chem. Phys., 4, 1461-1738, 2004, http://www.atmos-chem-phys.net/4/1461/2004/.

Atkinson, R., Baulch, D. L., Cox, R. A., Crowley, J. N., Hampson, R. F., Hynes, R. G., Jenkin, M. E., Rossi, M. J., and Troe, J.: Evaluated kinetic and photochemical data for atmospheric chemistry: Volume II - reactions of organic species, Atmos. Chem. Phys., 6, 3625-4055, 2005,

http://www.atmos-chem-phys.net/6/3625/2005/.

Benoît, R., Côté, J., and Méthot, A.: Inclusion of a TKE boundary layer parameterization in the Canadian Regional Finite-Element Model, Mon. Wea. Rev., 117, 1726-1750, 1989.

Bovensmann, H., Burrows, J. P., Buchwitz, M., Frerick, J., Noël, S., Rozanov, V. V., Chance, K. V., and Goede, A. P. H.: SCIAMACHY: Mission objectives and measurement modes, J. Atmos. Sci., 56, 127-150, 1999.

Burrows, J. P., Hölzle, E., Goede, A. P. H., Visser, H., and Fricke, W.: SCIAMACHY - Scanning imaging absorption spectrometer for atmospheric chartography, Acta Astronautica, 35, 445-451, 1995.

Burrows, J. P., Weber, M., Buchwitz, M., Rozanov, V., LadstätterWeißenmayer, A., Richter, A., DeBeeka, R., Hoogena, R., Bramstedt, K., Eichmann, K.-U., Eisinger, M., and Perner, D.: The Global Ozone Monitoring Experiment (GOME): Mission concept and first scientific results, J. Atmos. Sci., 56, 151-175, 1999.

Calvert, J. G. and Pitts, Jr., J. N.: Photochemistry, Wiley, New York, 1966.

Côté, J., Desmarais, J.-G., Gravel, S., Méthot, A., Patoine, A., Roch, M., and Staniforth, A.: The operational CMC-MRB Global Environmental Multiscale (GEM) Model. Part II: Results, Mon. Wea. Rev., 126, 1397-1418, 1998a.
Côté, J., Gravel, S., Méthot, A., Patoine, A., Roch, M., and Staniforth, A.: The operational CMC-MRB Global Environmental Multiscale (GEM) Model. Part I: Design considerations and formulation, Mon. Wea. Rev., 126, 1373-1395, 1998 b.

de Grandpré, J., Beagley, S. R., Fomichev, V. I., Griffioen, E., McConnell, J. C., Medvedev, A. S., and Shepherd, T. G.: Ozone climatology using interactive chemistry: Results from the Canadian Middle Atmosphere Model, J. Geophys. Res., 105, $26475-$ 26 491, doi:10.1029/2000JD900427, 2000.

Deardorff, J. W.: Efficient prediction of ground surface-temperature and moisture, with inclusion of a layer of vegetation, J. Geophys. Res., 83, 1889-1903, 1978.

DeMore, W. B., Sander, S. P., Golden, D. M., Hampson, R. F., Kurylo, M. J., Howard, C. J., Ravishankara, A. R., Kolb, C. E., and Molina, M. J.: Chemical Kinetics and Photochemical Data for Use in Stratospheric Modeling, Evaluation 12, JPL Publication 97-4, Jet Propulsion Laboratory, Pasadena, California, 1997.

Drummond, J. R.: Measurements of pollution in the troposphere (MOPITT), in: The use of EOS for studies of atmospheric physics, edited by: Gille, J. C. and Visconti, G., 77-101, NorthHolland, 1992.

Drummond, J. R. and Mand, G. S.: The Measurements of Pollution in the Troposphere (MOPITT) instrument: Overall performance and calibration requirements, J. Atmos. Ocean. Technol., 13, 314-320, 1996.

Edwards, D. P., Pétron, G., Novelli, P. C., Emmons, L. K., Gille, J. C., and Drummond, J. R.: Southern Hemisphere carbon monoxide interannual variability observed by Terra/Measurement of Pollution in the Troposphere (MOPITT), J. Geophys. Res., 111, D16303, doi:10.1029/2006JD007079, 2006.

Fishman, J., Hoell Jr., J. M., Bendura, R. D., McNeal, R. J., and Kirchhoff, V. W. J. H.: NASA GTE TRACE A Experiment (September-October 1992): Overview, J. Geophys. Res., 101, 23 865-23 880, doi:10.1029/96JD00123, 1996.

Fouquart, Y. and Bonnel, B.: Computations of solar heating of the Earth's atmosphere: A new parameterization, Contrib. Atmos. Phys., 53, 35-62, 1980.

Garand, L.: Some improvements and complements to the infrared emissivity algorithm including a parameterization of the absorption in the continuum region, J. Atmos. Sci., 40, 230-243, 1983.

Garand, L. and Mailhot, J.: The influence of infrared radiation on numerical weather forecasts, in: Proceedings of the Seventh Conference on Atmospheric Radiation, 23-27 July 1990, San Francisco, CA, pp. J146-J151, Amer. Meteor. Soc., 1990.

Gauthier, P., Charette, C., Fillion, L., Koclas, P., and Laroche, S.: Implementation of a 3D assimilation system at the Canadian Meteorological Centre. Part I: The global analysis., Atmos.-Ocean, 37, 103-156, 1999.

Gauthier, P., Tanguay, M., Laroche, S., Pellerin, S., and Morneau, J.: Extension of 3D-Var to 4D-Var: implementation of 4D-Var at the Meteorological Service of Canada, Mon. Wea. Rev., 35, 2339-2354, 2007.

Giguère, P. A. and Olmos, A. W.: Sur le spectre ultraviolet de l'acide peracétique et l'hydrolyse des peracétates, Can. J. Chem., 689-691, 1956.

Gong, S. L., Barrie, L. A., Blanchet, J.-P., von Salzen, K., Lohmann, U., Lesins, G., Spacek, L., Zhang, L. M., Girard, E., Lin, H., Leaitch, R., Leighton, H., Chylek, P., and Huang, P.: Cana- 
dian Aerosol Module: A size-segregated simulation of atmospheric aerosol processes for climate and air quality models, 1. Module development, J. Geophys. Res., 108, 4007, doi: 10.1029/2001JD002002, 2003.

Gong, S. L., Huang, P., Zhao, T. L., Sahsuvar, L., Barrie, L. A., Kaminski, J. W., Li, Y. F., and Niu, T.: GEM/POPs: a global 3D dynamic model for semi-volatile persistent organic pollutants - 1. Model description and evaluations, Atmos. Chem. Phys., 7, 4001-4013, 2007,

http://www.atmos-chem-phys.net/7/4001/2007/.

Grell, G. A., Peckham, S. E., Schmitz, R., McKeen, S. A., Frost, G., Skamarock, W. C., and Eder, B.: Fully coupled "online" chemistry within the WRF model, Atmos. Environ., 39, 6957-6975, 2005.

Hervig, M. E., Russell III, J. M., Gordley, L. L., Park, J. H., and Drayson, S. R.: Observations of aerosol by the HALOE experiment onboard UARS: A preliminary validation, Geophys. Res. Lett., 20, 1291-1294, 1993.

Horie, O. and Moortgat, G. K.: Reactions of $\mathrm{CH}_{3} \mathrm{C}(\mathrm{O}) \mathrm{O}_{2}$ radicals with $\mathrm{CH}_{3} \mathrm{O}_{2}$ and $\mathrm{HO} 2$ radicals between 263 and $333 \mathrm{~K}$, J. Chem. Soc., Faraday Trans., 88, 3305-3312, 1992.

Huang, P., Gong, S. L., Zhao, T. L., Neary, L., and Barrie, L. A.: GEM/POPs: a global 3-D dynamic model for semi-volatile persistent organic pollutants - Part 2: Global transports and budgets of PCBs, Atmos. Chem. Phys., 7, 4015-4025, 2007,

http://www.atmos-chem-phys.net/7/4015/2007/.

IPCC: Climate Change 2001: The Scientific Basis. Contribution of Working Group I to the Third Assessment Report of the Intergovernmental Panel on Climate Change, Cambridge Univ. Press, New York, NY, USA, 2001.

IUPAC: IUPAC Subcommittee on Gas Kinetic Data Evaluation for Atmospheric Chemistry, Data Sheet NOx11, 19 July 2005, http://www.iupac-kinetic.ch.cam.ac.uk/, 2005a.

IUPAC: IUPAC Subcommittee on Gas Kinetic Data Evaluation for Atmospheric Chemistry, Data Sheet HOx_VOC54, 17 February 2005, http://www.iupac-kinetic.ch.cam.ac.uk/, 2005b.

IUPAC: IUPAC Subcommittee on Gas Kinetic Data Evaluation for Atmospheric Chemistry, Data Sheet HOx_VOC3, 5 December 2005, http://www.iupac-kinetic.ch.cam.ac.uk/, 2005c.

IUPAC: IUPAC Subcommittee on Gas Kinetic Data Evaluation for Atmospheric Chemistry, Data Sheet HOx_VOC2, 21 July 2005, http://www.iupac-kinetic.ch.cam.ac.uk/, 2005d.

IUPAC: IUPAC Subcommittee on Gas Kinetic Data Evaluation for Atmospheric Chemistry, Data Sheet HOx_VOC36, 21 July 2005, http://www.iupac-kinetic.ch.cam.ac.uk/, 2005e.

IUPAC: IUPAC Subcommittee on Gas Kinetic Data Evaluation for Atmospheric Chemistry, Data Sheet ROO_1, 3 July 2005, http://www.iupac-kinetic.ch.cam.ac.uk/, $2005 f$.

IUPAC: IUPAC Subcommittee on Gas Kinetic Data Evaluation for Atmospheric Chemistry, Data Sheet HOx_VOC23, 8 June 2005, http://www.iupac-kinetic.ch.cam.ac.uk/, 2005g.

Jöckel, P., Tost, H., Pozzer, A., Brühl, C., Buchholz, J., Ganzeveld, L., Hoor, P., Kerkweg, A., Lawrence, M. G., Sander, R., Steil, B., Stiller, G., Tanarhte, M., Taraborrelli, D., van Aardenne, J., and Lelieveld, J.: The atmospheric chemistry general circulation model ECHAM5/MESSy1: consistent simulation of ozone from the surface to the mesosphere, Atmos. Chem. Phys., 6, 50675104, 2006,

http://www.atmos-chem-phys.net/6/5067/2006/.
Kaminski, J. W., Plummer, D. A., Neary, L., McConnell, J. C., Struzewska, J., and Lobocki, L.: First application of MC2-AQ to multiscale air quality modelling over Europe, Phys. Chem. Earth, 27, 1517-1524, 2002.

Kuo, H. L.: Further studies on the parameterization of the influence of cumulus convection on largescale flow, J. Atmos. Sci., 31, 1232-1240, 1974.

Landgraf, J. and Crutzen, P. J.: An efficient method for online calculations of photolysis and heating rates, J. Atmos. Sci., 55, 863878, 1998.

Langner, J., Robinson, L., Persson, C., and Ullerstig, A.: Validation of the operational emergency response model at the Swedish Meteorological and Hydrological Institute using data from ETEX and the Chernobyl accident - Description, test and sensitivity analysis in view of regulatory applications, Atmos. Env., 32, 4325-4333, 1998.

Laprise, R. and Girard, C.: A spectral general circulation model using a piecewise-constant finite-element representation on a hybrid vertical coordinate system, J. Climate, 3, 32-52, 1990.

Laroche, S., Gauthier, P., Tanguay, M., Pellerin, S., and Morneau, J.: Impact of the different components of $4 \mathrm{D}-$ Var on the global forecast system of the Meteorological Service of Canada, Mon. Wea. Rev., 35, 2355-2364, 2007.

Liu, S. C., Trainer, M., Fehsenfeld, F., Parrish, D. D., Williams, E. J., Fahey, D. W., Hubler, G., and Murphy, P. C.: Ozone production in the rural troposphere and the implications for regional and global ozone distribution, J. Geophys. Res., 92, 4191-4207, 1987.

Liu, X., Chance, K., Sioris, C. E., Spurr, R. J. D., Kurosu, T. P., Martin, R. V., and Newchurch, M. J.: Ozone profile and tropospheric ozone retrievals from the Global Ozone Monitoring Experiment: Algorithm description and validation, J. Geophys. Res., 110, D20307, doi:10.1029/2005JD006240, 2005.

Liu, X., Chance, K., Sioris, C. E., Kurosu, T. P., Spurr, R. J. D., Martin, R. V., Fu, M., Logan, J. A., Jacob, H. J., Palmer, P. I., Newchurch, M. J., Megretskaia, I., and Chatfield, R.: First directly retrieved global distribution of tropospheric column ozone from GOME: Comparison with the GEOS-CHEM model, J. Geophys. Res., 111, D02308, doi:10.1029/2005JD006564, 2006.

Logan, J. A.: An analysis of ozonesonde data for the troposphere: Recommendations for testing 3-D models, and development of a gridded climatology for tropospheric ozone, J. Geophys. Res., 104, 16 115-16 149, 1999.

Lurmann, F. W., Lloyd, A. C., and Atkinson, R.: A chemical mechanism for use in long-range transport/acid deposition computer modeling, J. Geophys. Res., 91, 10 905-10 936, 1986.

Mailhot, J.: The regional finite-element (RFE) model scientific description. Part 2: Physics, Documentation Manual available from RPN, Meteorological Service of Canada, Dorval, QC, Canada, M9P 1J3, 1994.

Mailhot, J., Chouinard, C., Benoît, R., Roch, M., and Verner, G.: Numerical forecasting of winter coastal storms during CASP Evaluation of the regional finite-element model, Atmos.-Ocean, 27, 24-58, 1989.

Marécal, V., Rivière, E. D., Held, G., Cautenet, S., and Freitas, S.: Modelling study of the impact of deep convection on the UTLS air composition - Part I: Analysis of ozone precursors, Atmos. Chem. Phys., 6, 1567-1584, 2006,

http://www.atmos-chem-phys.net/6/1567/2006/. 
Martin, R. V., Chance, K., Jacob, D. J., Kurosu, T. P., Spurr, R. J. D., Bucsela, E., Gleason, J. F., Palmer, P. I., Bey, I., Fiore, A. M., Li, Q., Yantosca, R. M., and Koelemeijer, R. B. A.: An improved retrieval of tropospheric nitrogen dioxide from GOME, J. Geophys. Res., 107, 4437, doi:10.1029/2001JD001027, 2002

Martin, R. V., Sioris, C. E., Chance, K., Ryerson, T. B., Bertram, T. H., Wolldridge, P. J., Cohen, R. C., Neuman, J. A., Swanson, A., and Flocke, F. M.: Evaluation of space-based constraints on global nitrogen oxide emissions with regional aircraft measurements over and downwind of eastern North America, J. Geophys. Res., 111, D15308, doi:10.1029/2005JD006680, 2006.

McFarlane, N. A.: The effect of orographically excited gravity wave drag on the general circulation of the lower stratosphere and troposphere, J. Atmos. Sci., 44, 1775-1800, 1987.

McLandress, C. and McFarlane, N. A.: Interactions between orographic gravity wave drag and forced stationary planetary waves in the winter northern hemisphere middle atmosphere, J. Atmos. Sci., 50, 1966-1990, 1993.

McLinden, C. A., Olsen, S. C., Hannegan, B., Wild, O., Prather, M. J., and Sundet, J.: Stratospheric ozone in 3-D models: A simple chemistry and the cross-tropopause flux, J. Geophys. Res., 105, 14 653-14666, 2000.

Molina, L. T. and Molina, M. J.: Absolute absorption cross sections of ozone in the 185- to 350-nm wavelength range, J. Geophys. Res., 91, 14 501-14 508, 1986.

Murphy, D. M. and Fahey, D. W.: An estimate of the flux of stratospheric reactive nitrogen and ozone into the troposphere, J. Geophys. Res., 99, 5325-5332, 1994.

Olivier, J. G. J. and Berdowski, J. J. M.: Global emissions sources and sinks, in: The Climate System, edited by: Guicherit, R. and Heij, B., pp. 33-78, A. A. Balkema Publishers/Swets and Zeitlinger Publishers, Lisse, The Netherlands, 2001.

Olivier, J. G. J., Bouwman, A. F., Berdowski, J. J. M., Veldt, C., Bloos, J. P. J., Visschedijk, A. J. H., van der Maas, C. W. M., and Zandveld, P. Y. J.: Sectoral emission inventories of greenhouse gases for 1990 on a per country basis as well as on $1^{\circ} \times 1^{\circ}$, Environ. Sci. Pol., 2, 241-263, 1999.

O’Neill, N. T., Campanelli, M., Lupu, A., Thulasiraman, S., Reid, J. S., Aubé, M., Neary, L., Kaminski, J. W., and McConnell, J. C.: Evaluation of the GEM-AQ air quality model during the Québec smoke event of 2002: Analysis of extensive and intensive optical disparities, Atmos. Environ., 40, 3737-3749, 2006.

Pickering, K. E., Wang, Y., Tao, W.-K., Price, C., and Müller, J.-F.: Vertical distributions of lightning $\mathrm{NO}_{x}$ for use in regional and global chemical transport models, J. Geophys. Res., 103, $31203-$ $31216,1998$.

Plum, C. N., Atkinson, R., Carter, W. P. L., and Pitts, Jr., J. N.: $\mathrm{OH}$ radical rate constants and photolysis rates of $\alpha$-dicarbonyls, Environ. Sci. Technol., 17, 479-484, 1983.

Richter, A., Burrows, J. P., Nüß, H., Granier, C., and Niemeier, U.: Increase in tropospheric nitrogen dioxide over China observed from space, Nature, 437, 129-132, 2005.

Sander, S. P., Friedl, R. R., Golden, D. M., Kurylo, M. J., Moortgat, G. K., Keller-Rudek, H., Wine, P. H., Ravishankara, A. R., Kolb, C. E., Molina, M. J., Finlayson-Pitts, B. J., Huie, R. E., and Orkin, V. L.: Chemical Kinetics and Photochemical Data for Use in Atmospheric Studies, Evaluation Number 15, JPL Publication 06-2, Jet Propulsion Laboratory, 2006.

Saunders, S. M., Jenkin, M. E., Derwent, R. G., and Pilling, M.
J.: Protocol for the development of the Master Chemical Mechanism, MCM v3 (Part A): tropospheric degradation of nonaromatic volatile organic compounds, Atmos. Chem. Phys., 3, 161-180, 2003, http://www.atmos-chem-phys.net/3/161/2003/.

Schultz, M. G., Heil, A., Hoelzemann, J., Spessa, A., Thonicke, K., Goldammer, J., Held, A., Pereira, J. M., and van het Bolscher, M.: Global wildland fire emissions from 1960 to 2000, Global Biogeochem. Cy., doi:10.1029/2007GB003031, in press, 2008.

Schumann, U. and Huntrieser, H.: The global lightning-induced nitrogen Oxides source, Atmos. Chem. Phys., 7, 38233907, 2007, http://www.atmos-chem-phys.net/7/3823/2007/.

Shindell, D. T., Faluvegi, G., Stevenson, D. S., Krol, M. C., Emmons, L. K., Lamarque, J. F., Petron, G., Dentener, F. J., Ellingsen, K., Schultz, M. G., Wild, O., Amann, M., Atherton, C. S., Bergmann, D. J., Bey, I., Butler, T., Cofala, J., Collins, W. J., Derwent, R. G., Doherty, R. M., Drevet, J., Eskes, H. J., Fiore, A. M., Gauss, M., Hauglustaine, D. A., Horowitz, L. W., Isaksen, I. S. A., Lawrence, M. G., Montanaro, V., Muller, J. F., Pitari, G., Prather, M. J., Pyle, J. A., Rast, S., Rodriguez, J. M., Sanderson, M. G., Savage, N. H., Strahan, S. E., Sudo, K., Szopa, S., Unger, N., van Noije, T. P. C., and Zeng, G.: Multimodel simulations of carbon monoxide: Comparison with observations and projected near-future changes, J. Geophys. Res., 111, 24, 2006.

Stevenson, D. S., Dentener, F. J., Schultz, M. G., Ellingsen, K., van Noije, T. P. C., Wild, O., Zeng, G., Amann, M., Atherton, C. S., Bell, N., Bergmann, D. J., Bey, I., Butler, T., Cofala, J., Collins, W. J., Derwent, R. G., Doherty, R. M., Drevet, J., Eskes, H. J., Fiore, A. M., Gauss, M., Hauglustaine, D. A., Horowitz, L. W., Isaksen, I. S. A., Krol, M. C., Lamarque, J. F., Lawrence, M. G., Montanaro, V., Muller, J. F., Pitari, G., Prather, M. J., Pyle, J. A., Rast, S., Rodriguez, J. M., Sanderson, M. G., Savage, N. H., Shindell, D. T., Strahan, S. E., Sudo, K., and Szopa, S.: Multimodel ensemble simulations of present-day and nearfuture tropospheric ozone, Journal of Geophysical ResearchAtmospheres, 111, D08301, doi:10.1029/2005JD006338, 2006.

Stockwell, W. R. and Lurmann, F. W.: Intercomparison of the ADOM and RADM Gas-Phase Chemistry Mechanisms. Report prepared for the Electric Power Research Institute, Electric Power Research Institute, 1989.

Struzewska, J. and Kaminski, J. W.: Formation and transport of photooxidants over Europe during the July 2006 heat wave observations and GEM-AQ model simulations, Atmos. Chem. Phys., 8, 721-736, 2008,

http://www.atmos-chem-phys.net/8/721/2008/.

Sundqvist, H.: A parameterization scheme for non-convective condensation including prediction of cloud water content, Quart. J. Roy. Meteor. Soc., 104, 677-690, 1978.

Sundqvist, H.: Prediction of stratiform clouds: Results from a 5-day Forecast with a global model, Tellus, 33, 242-253, 1981.

Talukdar, R. K., Longfellow, C. A., Gilles, M. K., and Ravishankara, A. R.: Quantum yields of $\mathrm{O}\left({ }^{1} \mathrm{D}\right)$ in the photolysis of ozone between 289 and $329 \mathrm{~nm}$ as a function of temperature, Geophys. Res. Lett., 25, 143-146, 1998.

Thompson, A. M., Witte, J. C., McPeters, R. D., Oltmans, S. J., Schmidlin, F. J., Logan, J. A., Fujiwara, M., Kirchhoff, V. W. J. H., Posny, F., Coetzee, G. J. R., Hoegger, B., Kawakami, S., Ogawa, T., Johnson, B. J., Vömel, H., and Labow, G.: Southern Hemisphere Additional Ozonesondes (SHADOZ) 1998-2000 
tropical ozone climatology 1. Comparison with Total Ozone Mapping Spectrometer (TOMS) and ground-based measurements, J. Geophys. Res., 108, 8238, doi:10.1029/2001JD000967, 2003a.

Thompson, A. M., Witte, J. C., Oltmans, S. J., Schmidlin, F. J., Logan, J. A., Fujiwara, M., Kirchhoff, V. W. J. H., Posny, F., Coetzee, G. J. R., Hoegger, B., Kawakami, S., Ogawa, T., Fortuin, J. P. F., and Kelder, H. M.: Southern Hemisphere Additional Ozonesondes (SHADOZ) 1998-2000 tropical ozone climatology 2. Tropospheric variability and the zonal wave-one, J. Geophys. Res., 108, 8241, doi:10.1029/2002JD002241, 2003 b.

Thornton, J. A., Braban, C. F., and Abbatt, J. P. D.: N2O5 hydrolysis on sub-micron organic aerosols: the effect of relative humidity, particle phase, and particle size, Phys. Chem. Chem. Phys., 5, 4593-4603, 2003.

Tulet, P., Crassier, V., Solmon, F., Guedalia, D., and Rosset, R.: Description of the Mesoscale Nonhydrostatic Chemistry model and application to a transboundary pollution episode between northern France and southern England, J. Geophys. Res., 108, 4021, doi:10.1029/2000JD000301, 2003.

Venkatram, A., Karamchandani, P. K., and Misra, P. K.: Testing a comprehensive acid deposition model, Atmos. Environ., 22, 737-747, 1988.
Wesely, M. L.: Parameterization of surface resistances to gaseous dry deposition in regional-scale numerical models, Atmos. Environ., 23, 1293-1304, 1989.

Yeh, K.-S., Côté, J., Gravel, S., Méthot, A., Patoine, A., Roch, M., and Staniforth, A.: The CMC-MRB Global Environmental Multiscale (GEM) Model. Part III: Nonhydrostatic Formulation, Mon. Wea. Rev., 130, 339-356, 2002.

Yu, W., Garand, L., and Dastoor, A. P.: Evaluation of model clouds and radiation at $100 \mathrm{~km}$ scale using GOES data, Tellus A, 49, 246, 1997.

Zhang, G. J. and McFarlane, N. A.: Sensitivity of climate simulations to the parameterization of cumulus convection in the CCCGCM, Atmos.-Ocean, 3, 407-446, 1995.

Zhang, L., Moran, M. D., Makar, P. A., Brook, J. R., and Gong, S.: Modelling gaseous dry deposition in AURAMS: a unified regional air-quality modelling system, Atmos. Environ., 36, 537560, 2002.

Zhang, Q., Streets, D. G., He, K., Wang, Y., Richter, A., Burrows, J. P., Uno, I., Jang, C. J., Chen, D., Yao, Z., and Lei, Y.: $\mathrm{NO}_{x}$ emission trends for China, 1995-2004: The view from the ground and the view from space, J. Geophys. Res., 112, doi: 10.1029/2007JD008684, 2007. 